$1 \mathrm{H} 1415$

ウシ蘭シアログリコペプチド(S GP) によるPC 12 緗胞の

アポトーシスの鹤

○小林莱子 佐伯伐彦 策沢隆雄 （群大・エ）

ウシ脳シアログリコペプチド (SGP) は、種々の細胞のDNA合成を 抑制すると報告されている分子量 18 Kの栯蛋白覧である。この蛋白筫は

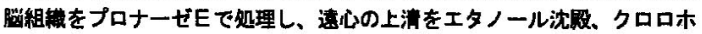
ルムーメタノール抽出を行うことによって得られる。昨年度の本大会で、

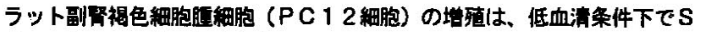
GPIよって影著に抑制されることを辄告した。今回は、このSGPによ る增冝抑制が何に起因するか摸捨を础みた。

細胞の增残扣制は、分化あるいは死によって生しるる分化は生であり、 生と死は、様々な方法で判定することができる。ミトコンドリア内の脱水 素称集活性を測定するMT T法も死を判定する一つの方法である。緗胞死 には、アポトーシスとネクローシスがある。アポトーシスでは、細胞は収 盽し、DNAはヌクレオソーム単位 (180 b p 単位)に断片化される。

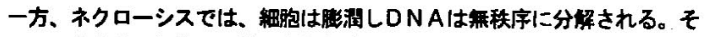
こで、SGPの細胞への作用を算析するために、（1）MT T法による細

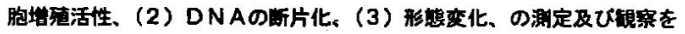
行った。

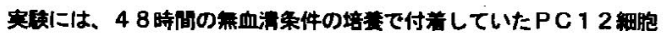
(Serum Deprivation Resistant, SDR P C 12 細胞) を用いた。この細 胞は血浅の添加により堷琶し、生存能力を維持している。SDRPC 12

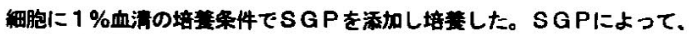

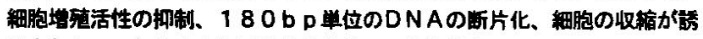
発された。これらの変化はNGF存在下でも生した。

以上のことから、SGPによるPC1 2 絊胞の塔党抑制は、死、すなわ ち、アポトーシスに起因すると示㕹される。

Yoko Kobayashi, Toshihiko Saheki. Takao Shinozawa: The induction of PC12 cell death, apoptosis, by the sialoglycopeptides.

$1 \mathrm{H} 1445$

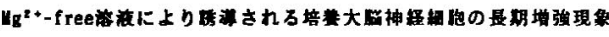

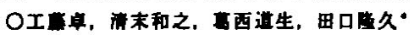

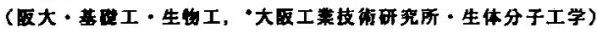

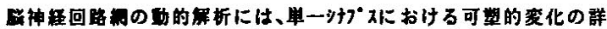

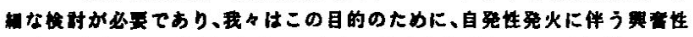

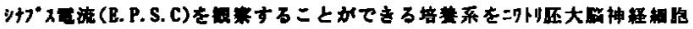

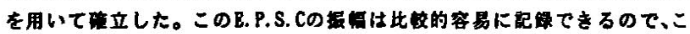

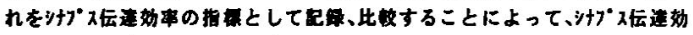

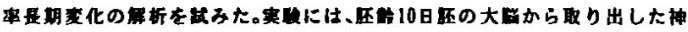

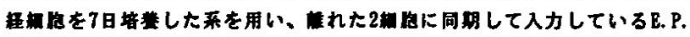

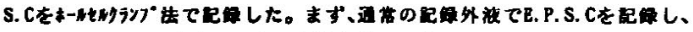

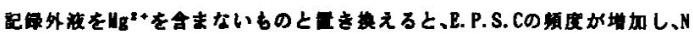

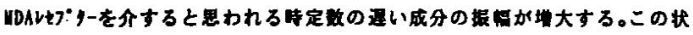

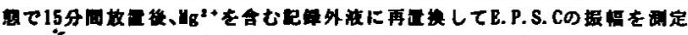

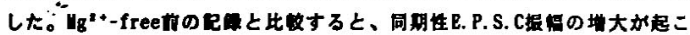

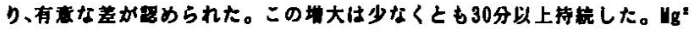

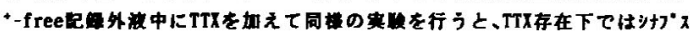

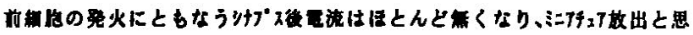

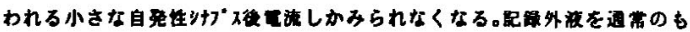

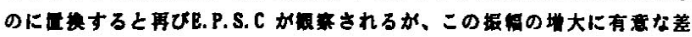

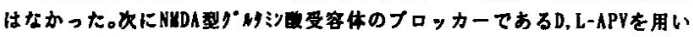

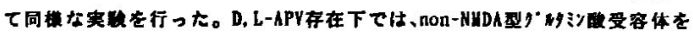

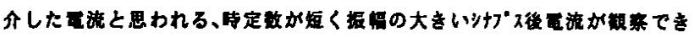

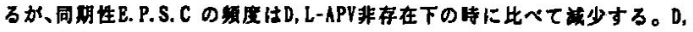

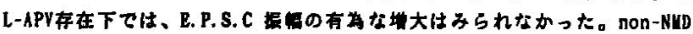

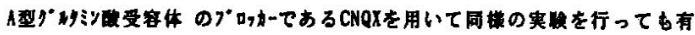

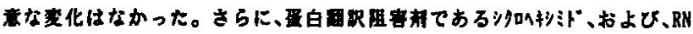

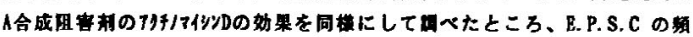

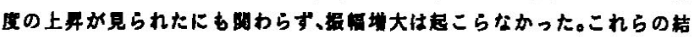

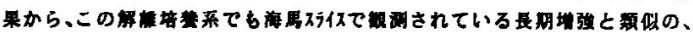

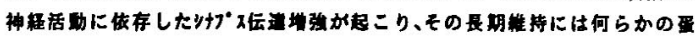
自合成吕还空ておること加明らかにたった。

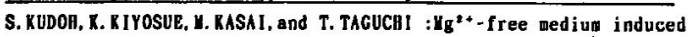
long-tero potentiation in dissociafed chick cerebral neurons.
1 H 1430

ウミウシの連合学習に関わろタンパク澌と相同なタンパ

ク質のショウショョバエ頭部からの精軴

0 井上宏子、吉岡亨、高满正身・ (早船田大学・人間科学部、 “三渂生命研)

ウミウシを光と回転により条件付けした時に、視蛽胞のKコンダ クタンスが低下することが知られているが、これにはある㮔の低分 子岳Gタンパク質(cp20)か関与していると考えられている。我ゃは このcp20を認識する抗体を用いて、cp20之相同なタンパク質(cp20 粎タンパク質)がショウジョウパエ幁部に存在することを見出した (昨年の大会で報告)。今回は、このタンパク質を棈慗し、その部分 アミノ酸配列を調へたのて、その結果を辄告する。

八エのcp20梯タンバク質は頭部の可溶性分面に存在するのて、、可 溶性分画を抽出し、イオン交換クロマトグラフィーで部分情製した。 その結果、このタンパク質の分子吾はSDS-PAGEで24 kDaでおった か、明確なGTPYS結合活性は見られなかった。また、このタンパク 質の部分アミノ酸配列を分析したところ、これまで损告されてい ろタンパク質とのホモロジーは見られなかった。

H. Inoue, T. Yoshioka, M. Takahasi: Purification of a protein from Drosophila heads homologue of conditioning associated protein in Hermissenda .

$1 \mathrm{H} 1500$

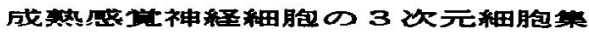
合によるNGF応管增强の梂橉 ○嚗江添典、赤城良子

棈浜市大・医・生理

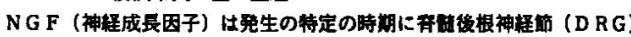
からの神释再生を缯く促進し、成量に伴いその作用が低下して行くと考え

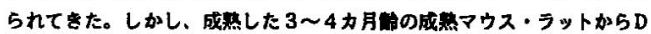

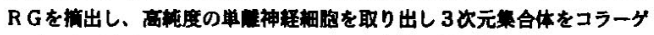

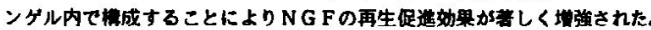

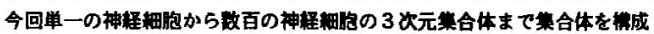

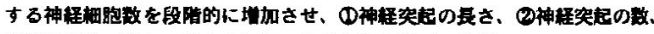

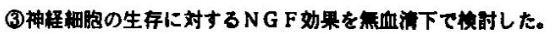

コラーダンダル内で単一の神経䚀胞に対するN G F の神絟突起成長促進

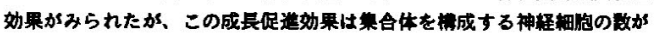

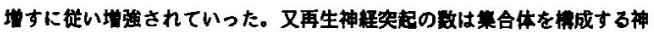

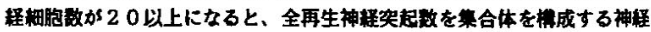

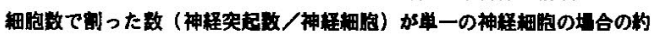

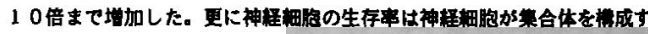
ることにより改善され、NGF

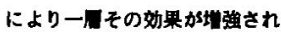
た (困)。以上のように成恝 荧神経湅胞は 3 次元湅胞集合を

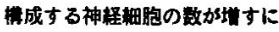
従いN G F の再生促進效果を坦 强していった。その結果数千個 の神経緗胞の集合呠加5N G F の作用下て神経以外の緭胞の助 けを借りることなく胎生期同林 の㟋い神経突护再生応答を示し たと考えられる。

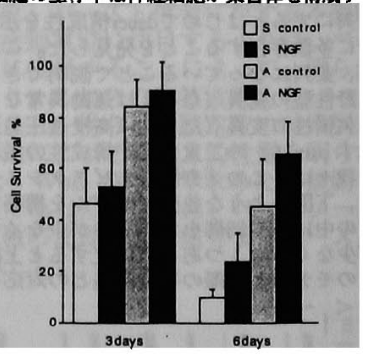

(図) $S:$ 早一の神緼細胞 A : 10〜50の神経解胸の集合体
H. Horie. Y. Akahori : Hechanisa of enhancement of adult sensory neuron response to NGF induced by three-dinesional cell aggregation. 


\section{H 1515}

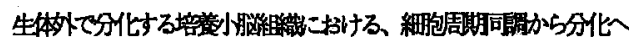
の神程グリア相互閂係

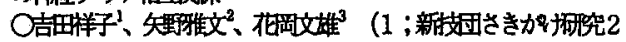

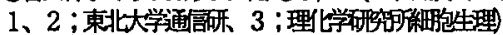

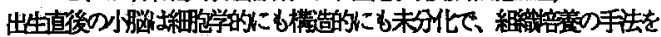

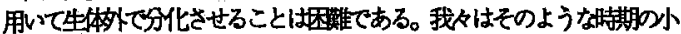

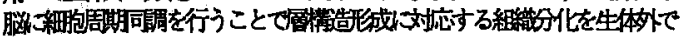

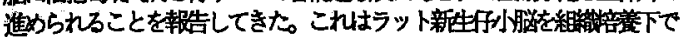

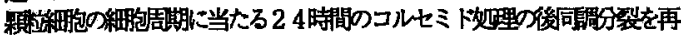

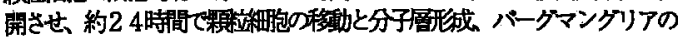

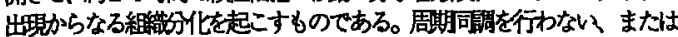

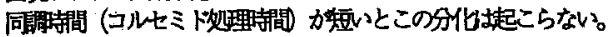

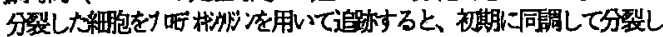

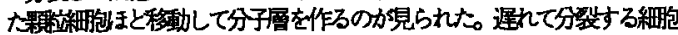

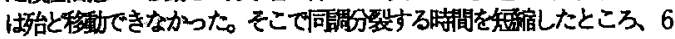

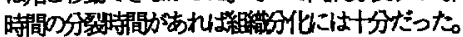

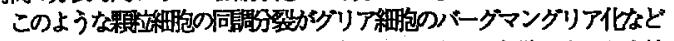

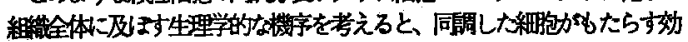

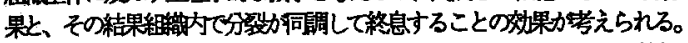

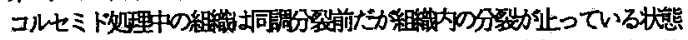

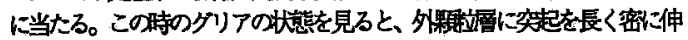

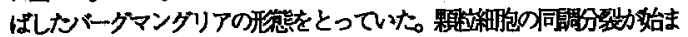

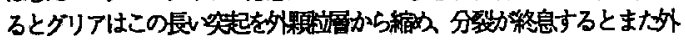

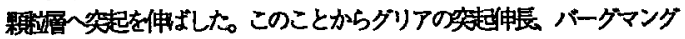

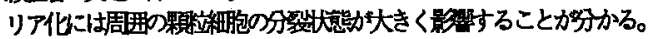

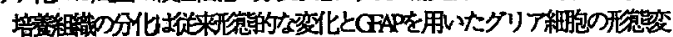

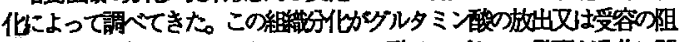

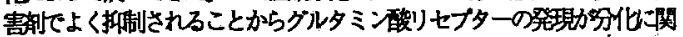
与することか宗棱された。そこで今回グルタミン酸りセブターのフンタゴ

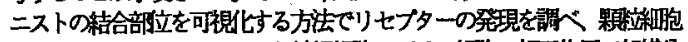

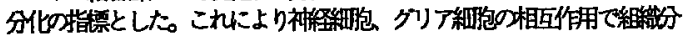

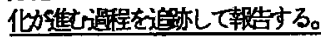

S.Yoshida, M. Yano, F. Hanaoka: Developmentof neuron-glia

interaction in cerebellar differentiation in vitro

\section{$1 H 1545$}

NO微小里椣の中枢神経領域におけけるin vivo応用

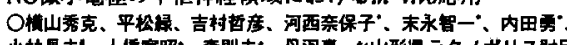

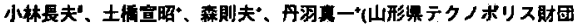

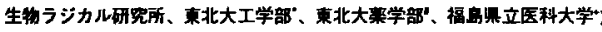

NOは無機ラジカルのひとつである。近年、生体内におけるNOの理各 の作用が检討され、中枢神経の領域においていフリーラジカルとして の挙功に䦗心がもたれている。これまで、生体内のNOの消失速度が速 いため、in vivo 测定は困難とされてきた。しかし、Malinskiら(Nature,

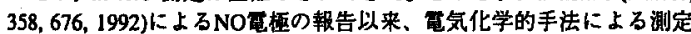
が往目されている。本研究では、彼らが考案したす法に基づいてNO殿

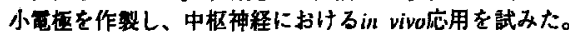

まず、カーボンファイパー( $\phi 10 \mu \mathrm{m})$ をテフロン溶湤を用いて1本つ つ緦緣したものを東にしてエボキシ榯脂を用いてガラス管 $(\phi 1 \mathrm{~mm})$ 内に 封入し、その断面を研磨してカーボンフフイパー西極として用いた。 この梅を0.1N NaOHを含むlmMONickel Tetrakis (3 - methoxy - 4 - hydroxy - phenyl) Porphyrin (Ni-TMHPP)浴液中においてスキャン (-200-1200mV vs 鵤和カ口メル西極)し、Ni-TMHPPを断面に酸化㫣解 重合した。重合後、電極を5\%低級アルコールを含むナフィオン溶液に 㜔港し、風乾の後、NO微小椣の作用極として使用した。対極には白

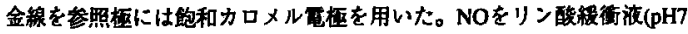

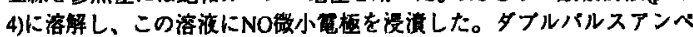

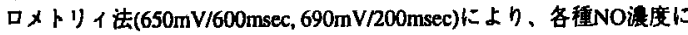
対応した触媒酸化菓流值の㭘量線を得た。

ウレタン麻醉下(1 $/ \mathrm{kg}$ i.p.)のラットに、定位的に左側感覚運軼領野皮

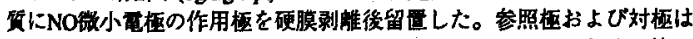
対側硬膜外に留贯した。繶いて、タブルバルスアンベロメトリィ法に て奄流値を経時的にモニターしながら、媨内のNO合成醇素を賦活寸る と考えられている物澌であるNMDA $(90 \mathrm{mg} / \mathrm{kg})$ を腹胵内投与した。その

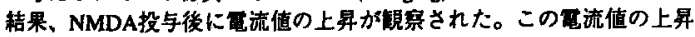
と、NMDA刺激による皮啠でのNO清度の上昇を、梌量線より对応つけけ た。

H. Yokoyama, M. Hiramatsu, T. Yoshimura, N. Kasai, T. Matsue, I. Uchida, N. Kobayashi, N. Tsuchihashi, N. Mori, S. Niwa: In vivo application of NO micro-electrode for central nerves system tesearch.

\section{$1 \mathrm{H} 1530$}

低分子量 G 蛋白倎エフェクタ一領域によるラット小莤ブルキ ンエ和胞のカリウム敢流の㧕制

O洨边 恵 ${ }^{1} \cdot$ 高木 博 $^{2} \cdot$ 井上宏子 $^{3} \cdot$ 吉田 明 $^{3} \cdot$ 吉网 高 ${ }^{3}$. 桐野 豊 ${ }^{1}$ ('東大·薬、 ${ }^{2}$ 早大·理工·物理、 ${ }^{3}$ 早大·人科-分子 神経生物)

カリウムチャネルのコンダタタンスの変化は神経活動の部節にとっ

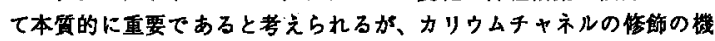
搆はこれまでほとんど明らかにされていない。

GTP 結合蛋白復には、3量体棈造を持つ高分子量G 蛋白質の他に，

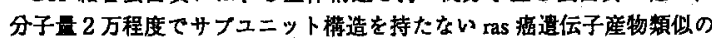
一群の $\mathrm{G}$ 蛋白劦（低分子量 $\mathrm{G}$ 蛋白望）が存在する。低分子量 G 蛋白贸 の中で、 rab3AL は神释終末での伝達物質放出に関保しているとされて おり、またrasはウミウシなどでカリウムチャネルを修飾する墈きがあ ることが知られている。このような事実から低分子量 $\mathrm{G}$ 蛋白質が神経 活動の調節に重要であると考えられる。

我々は whole cell バッチクランブ法によりラット小腷スライスのブル キンエ細胞の策位依存性カリウム電流测定した。細胞内に rab3AL お よび rasのエフェクター領城（標 的蛋白䁲との結合領域）に相当す る合成ペブチドを注入してそれら の効果をみると、 rab3ALのエフェ

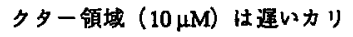
ウム西流を影著に減少したが、一 方 $\operatorname{ras}$ のエフェクター領域 (100

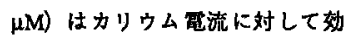
果を示さなかっった。

以上の秸果は rab3ALがカリウ ムチャネルを修飾する墈きを持つ Fig: Outward current after injection ことを示唆している。

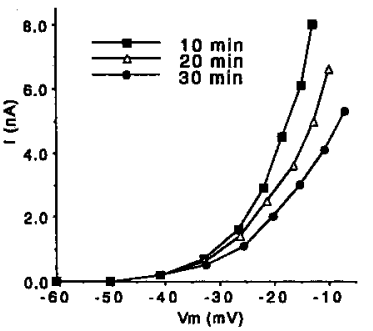

S. Watanabe, H. Takagi, H. Inoue, A. Yoshida, T. Yoshioka \& Y. Kirino: Reduction of potassium current in rat cerebellar Purkinje cells by the effector domain of a small $G$ protein.

\section{$1 \mathrm{H} 1600$}

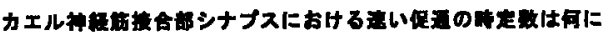 よって決まるか (その2) \\ O过 文子、小山内 実、鉿木直哉、木島博正 \\ (名大・理・物理)}

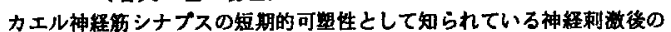

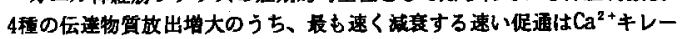
卜刺BAPTAをシナプス前柛経末端に負荇することによって完全に消失するこ とから、神経末端内の牫存遊影 $\mathrm{Ca}^{2+}$ (践存 $\left[\mathrm{Ca}^{2+}\right]_{1}$ ) によって起こると考 えられる。樶近のZuckerらのCagedキレート制を用いた実硂もこれを支持し ている。

前年の本年会で私達は、BAPTAを速い促通の大きさが目荷前の1/2 1/3程 度になるように負荷した場合の、これの娍育の時定数を調へ、この時定数か 2割程度大きくなるが、放出汃 $\left[\mathrm{Ca}^{2+}\right]$,のn乗 $(\mathrm{n}=4 \sim 5)$ に比例して起 こる $\left(\mathrm{n}\right.$ 乘則) ことを仮定して $\left[\mathrm{Ca}^{2+}\right]_{1}$ の減衰時定数を計算すると、この 時定敉は目荷前と变わらないことを報告した。この結果は、 $\left[\mathrm{Ca}^{2+}\right]$ ，の減 衰が $\mathrm{Ca}^{2+}$ 低親和性のポンプによるという考えとは矛盾する。一方ニュー口 ンやクロム粯和性細胞内には、低新和性の固定 $\mathrm{Ca}^{2+}$ ハヘッファーが大量に存

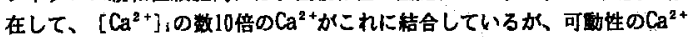
は少ないことが知られており、シナブス前末蝡でも同模のことが予想され

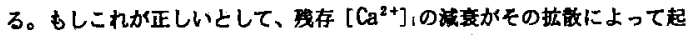

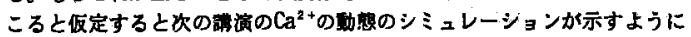
BAPTA角荷によって城衰の時定制は大愊に娍少するはずでる。従ってこの 仮定も実挽結果には矛盾することかかかった。またシミュレーションの結 果によると、拉散による減衰の時定数はこのシナプスではm以下にしかな らず、約40西という実結果を䂱明できなっった。

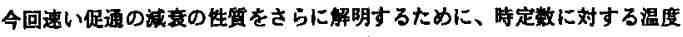

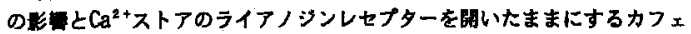

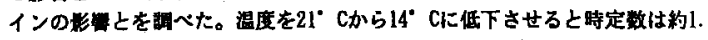
4倍に增大した。これは自由㹡散に対して期待される温度奶果よりは少し大 きいが、ATPをエネルギー源とするポンブに对する温度奻果よりは小さい。

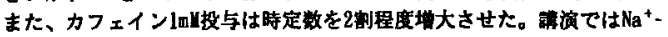
$\mathrm{Ca}^{2+}$ 交涣体の阻曾制の奻果についても述へる予定である。

A. Tsuji, M. Osanai, N. Suzuki, H. Kijima: What determines the time-constant of fast component of facilitation at the frog neuromuscular synapse,(II). 
$1 \mathrm{H} 1615$

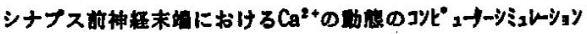

O木岛 博正、小山内 実、过 文子、鈴木 直戴、

饭田壮象、木島 样子（名大・理・物理）

シナプス前神経末端からの神経伝達物貿放出は、末端の細胞内遊部 $\mathrm{Ca}^{2+}$ 灌度 $\left[\mathrm{Ca}^{2+}\right]_{1}$ の上界によってトリガーされることがかかっているが その機楼はまだ明らかでない。最近のイカ巨大シナプス前末端のイメー

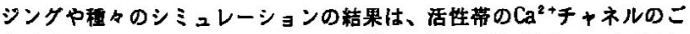
く近位では、チャネルの開口時に $\left[\mathrm{Ca}^{2+}{ }^{+}\right.$、は数百 $\mu$ 川に逢することを示

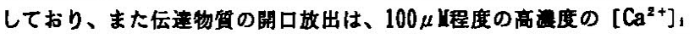
によってトリガーされるという考えが有力なようにみえる。前謴演で述 へたように、我々は速い促通の原因と推定されるインパルス到逢後の牫

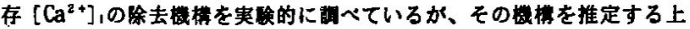

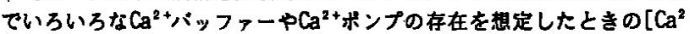

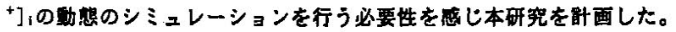

前の垟演で述へたようにニューロンやシナプス前神释末端には低親和

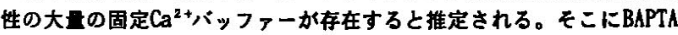
やFura2のような $\mathrm{Ca}^{2+}$ と同程度の拉故定数を持つ可徝性パッファーが存

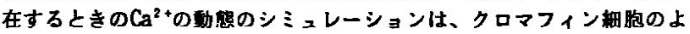
うな球状の相胞については行われているか、カエルやエビの神経肠シナ プスやイカの巨大シナブスのような畨状や棈円状の活性带についてはま だ行われていない。今回我々は、カエルとエビのシナブス前活性帯のモ デルとなる長方形及ひ、半冈形の細胞について、固定及び可動バッファ

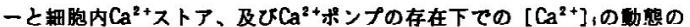
コンビューターシミュレーションを行った。その結果㰠のことが明らか になった。

（1以前に示した可野バッファーと同しく固定バッファーの存在も、 $\mathrm{Ca}^{2+}$ チャネルのこく近销に成される $\left[\mathrm{Ca}^{2+}\right]$ 、のビークに対しては小さ な影雾しか与えない。

（2大贯の低親和性固定バッファーが存在するときに、BAPTAのような可

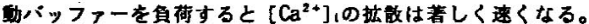

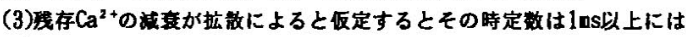
なり得ない。

H. Kijima, M Osanai, A, Tsuji, N. Suruki, S, Iida, S. Kijima : Computer

simulation of free $\mathrm{Ca}^{2+}$ at the presynaptic nerve terminal

\section{$1 \mathrm{H} 1645$}

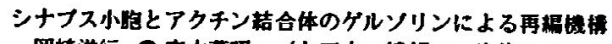
网绮洋行 ○宮本茂昭 (九工大. 情報工、生化システム)

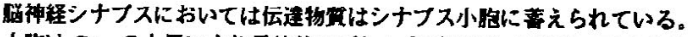

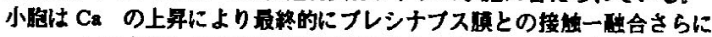

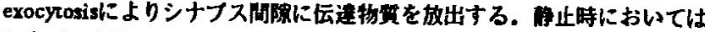
シナプス小炮はsynapsin 1を通してactin filamentのnetworkにつながれてい ろ. Ca の

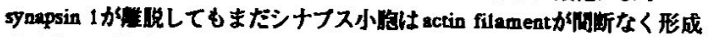

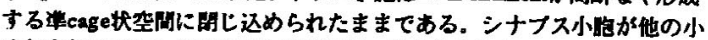

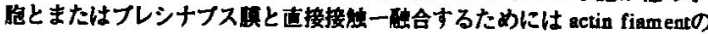
networkが解消せねばならない.Ca 侑存的にactin filamentを切断する因 子としてgelsolinまたはgelsolin-likeな分子の存在が報告されている。本研

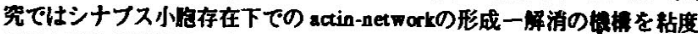

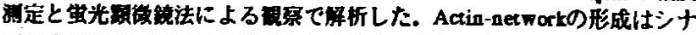
ブス小存在下ではより促進されること、またシナフス小胞の actin

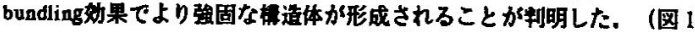

参照)この珹固な梅造体は Ca 传存的にgelsolinにより切断されシナフ

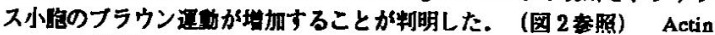

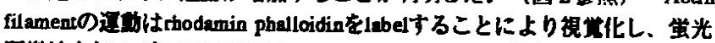

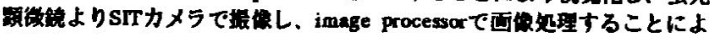

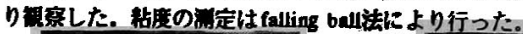
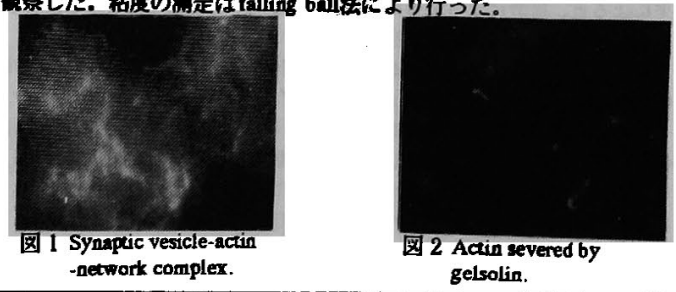

Hiroyuki Okazaki \&Shigeaki Miyamoto: The reorganization of synaptic vesicle and actin network complex by gelsolin.
$1 \mathrm{H} 1630$

カエル神経筋接合部における神経伝達物霓放出に対 するTrinnitrobenzene(TNB)アナログの効果 ○小山内 実、过文子、鈴木直哉、木岛博正 (名大 - 理)

カエルの神䅅筋接合部シナプスでは、神経刺激後の神経伝连 物所の故出增大に、その時定数により4つの種類がある事が知ら れている。これまでに我々は、放出增大のうち早い促通(fast

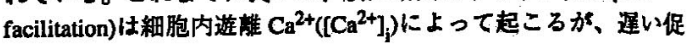
通(slow facilitation)と增進(augmentation)、增強(potentioation)仕 $\left[\mathrm{Ca}^{2+}\right]_{\mathrm{i}}$ によって起こっているのではない事を確かめていた。ま た、アミノ基修飾試来として知られている 2,4,6-Trinitrobenzenesulfonic Acid (TNBS)が、トノサマガエルの神経筋接合部シナブ ス前末端に影䜌を及ほして、伝達物兵の放出が者しく増大し、 その後減少していくという車も明らかにしていた。さらにこの 伝達物顺放出增大は、 $\left[\mathrm{Ca}^{2+}\right]_{\mathrm{i}}$ によるものではない事も確かめら れていた。そこで、この伝達物领放出の增大は $\left[\mathrm{Ca}^{2+}\right]_{\mathrm{i}}$ によらな い刺漖後の放出增大と共通の分子機㜔よって起こっているのて はないかと考え、剌救後の放出增大がTNBSによってとのような 影䡒を受けるか調べた。

また、TNBS と 2-Aminoethanol の反応物をシナプスに与えて も同棦に神释伝達物斦の故出增大が起こった。この事から、伝

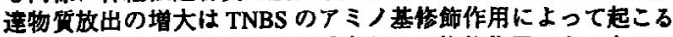
のではなく、その後の放出の減少がこの攸飾作用によるものて あるという事が分かった。そこでこ反応物 1-(2-Hydroxyethylamino)-2,4,6-Trinitrobenzene(HEATNB)を精製しその作用を調べ た。その結果、HEATNB は $0.2 \mathrm{mM}$ 程度で安定した長時間に波 る放出增大を引き起こす事が判明した。またこの作用は、この 程度の浱度では可逆的であり、放出の增大に对して港度依存性 がある。さらに、HEATNBは刺激後伝羊物留放出增大の各成分 に影帮を与えるようであるが、特に增强の成分を増加させた。

M. Osanai, A. Tsuji, N. Suzuki, H. Kjjima : Effects of Trinitrobenzene (TNB) Analogs on the Transmitter Release at Frog Neuromuscular Junction

$1 \mathrm{H} 1700$

PC12細路におけるオートレセブター応答

高本博、吉田明、石井亮次、吉岡享

(早稆田大学・分子神経生物)

シナプス前終末には、様々な生理活性物質に対する受容体が存 在しており、これらを介してシナプス前終末の機能が調節されている。 しかし、シナプス前受容体の性質や調飾の細胞内機序についての詳伡 はほとんど明らかにされていない。特にシナプス前終末より故出され た伝連物質をそれ自身が受容するオートレセブターは、非常に重要な役 割を担っていると考えられているがその実体はこく一部の細盷（たと えばチック毛梾体二ューロン) てしかその解析が進められてはいない。

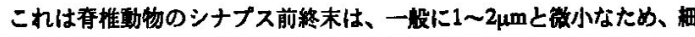
胞生理学アプローチが困難であることに起因している。我々はこのオ ートレセプタ-を解析する目的のために、シナプス前整末のモテル細枹 として知られるPC12細胞を用いて放出された伝達物質のシナプス前受 容体への作用機櫵を険郡してみた。なぜならば、PC12細胞は伝道物質 としてATPを放出することと、ATPに対する受容体を持つことが知ら れているからである。

PCl2細胞よりホールセル紀録を行った。膜電位を-60mVに保持 するだけで、 unit size 約20pA、半堿期 $(\tau)=$ 約20msec の内向き党流 が記䟿された。この電流の振幅は膜電位依存的に変化し、その反枟草

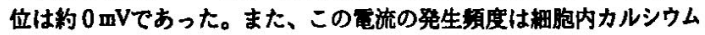
湌度に比例して增加し、湅胞内にEGTAを注入すると減少した。更に、 この篦流はATP受容体の阻害制であるスラミン $(100 \mu \mathrm{M})$ によって可逆的 に阻害されたが、ニコチン性アせチルコリン受容体の阻害刺でるへ

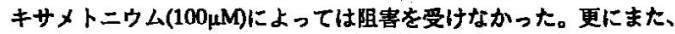

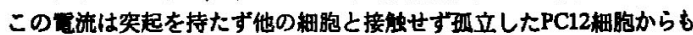
記䩮することが出来た。これらの事実からPC12細胞より默緑されるこ の内向き電流は、PC12細眴から開口分泌されたATPがその細胞自身の ATP受容体に作用することにより得られる応答（オートレセプタ-応答） てあることが判った。 Autoreceptor response in PC12 cells : H. Takagi, A. Yoshida, R. Ishit and T. Yoshioka (Department of Molecular Neurobiology, Waseda University) 


\section{$1 \mathrm{H} 1715$}

ラット镃とシビレエイ電気器官のシナブス小胞の比较

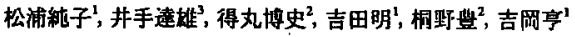
'早程田大学・人間科学部 ${ }^{2}$ 東京大学・莯学部

'九州大学・楽学部

学習の成立過程において、シナプスに可盟的な贽化が起きること は明らかになっているが、その変化がブレシナプス側で起きている のか、ポストシナプス侧で起きているのかは明かにされていない。 プレシナプスは大柗小さく、電気生理学的手法で解析することが团 㯇であるため、神経伝達物貿故出のメカニスムについては、まだほ とんど解明されていない。その解明のためには、プレシナプス形質 膜やシナプス小胞を単䊒し、その膜表面に存在するタンパクの相互 作用を研究する必要がある。

記境、学習といった高次脱機能の研究には、哺乳類の脱を矿究对 象とする必要がある。中でも新鲜な脱の人手しやすいラットがよく 用いられている。しかし哺乳類の腷は栏々な种経伝達物犋を含むシ ナプス小胞を有するという困難がある。一方、シビレエイの筐気器 官は种経伝達物質としてアセチルコリンのみを含むシナプス小绚を 有するため解析を行いやすい。これまで、両者を詳細に比较した㑚 究はほとんど行われていない。そこて、本研究ては、シビレェイ電 気器官とラット眇から単㫿したシナプス小胞の膜タンパクの間の相 同性を検討した。

二㮔類のシナプス小胞について種々の抗体を用いてWestern blot称 析を行ったところ、抗シナプトフィジン抗体はシビレエイと交叉し たか、反応したバンドの分子量が異なっており、抗シナプトタグミ ン抗体は交叉しなかった。この結果から、シビレエイのシナプス小 盷とラットのシナプス小胞では、その表面にあるタンパク質の楼造 が異なっていることが考えられるが、他の抗体についても梌討中て ある。また、シナプス小胞調製時の Sucrose density gradient centrifugationにおいて、各画分のATP量を测定したところ、コリン作 怔性种経のみを含むシビレエイ電気器官のシナプス小咆では、シナ プトフジンの分布と一致したか、ラット磁では一致しなかった。 J.Malsura, T.Ide, H.T okumanu, A. Yoshida, Y.Kirino, \& T.Y. Yoshioka:

Comparison between synaptic vesicles from rat brain and from electric organ

\section{0}

ニワトリ松果体の生物時計に入カナる光估数伝㟟释路の解析

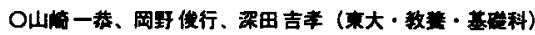

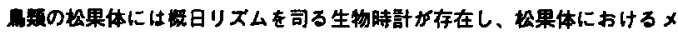

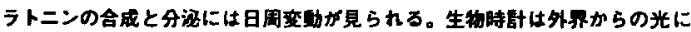

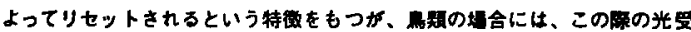

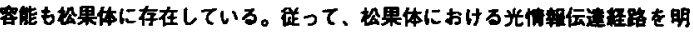
らかにナることは、生物時計の分子メカニスムを鲜明する手がかりにるると 考えられる。

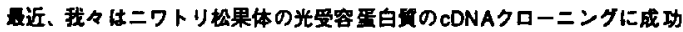

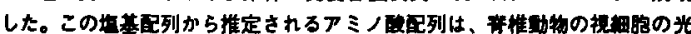

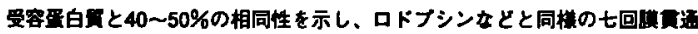
型情造をとると思われる。この迹伝子を293EBNA用胞において搏制発現さ

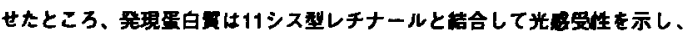

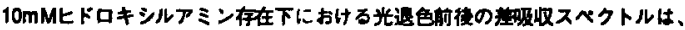

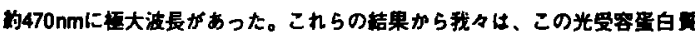
をピノブン（Pinopsin= Opsin in pinealocyte）と命名した。

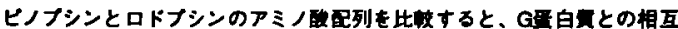
作用㭌位において重い相同珄現られる。このことから、松果体にも光受客

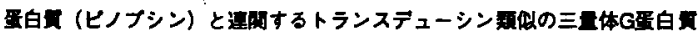

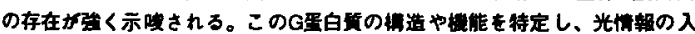
力先を同定でれれは、生物時計本体に迫ることがでるるそこで我々は、ニ ワトリ松果体の三基体G蛋白罢、特にエフェクター分子と相互作用すると思

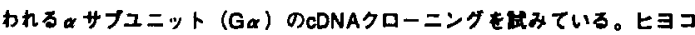

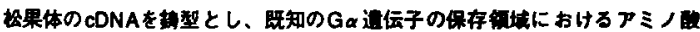
列に基コくブライマーを用いてPCR法を行ったところ、梘拥胞のトランス

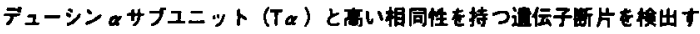

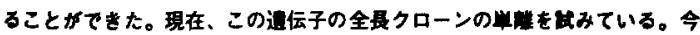

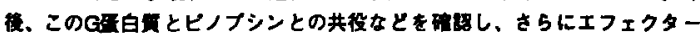

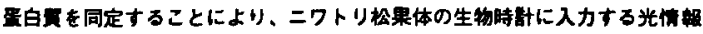
伝遗系路を解析する予定である。

K.Yamazaki, T.Okano, Y.Fukada :Analysis of pholotransduction pathway to the circadian pacemaker in chicken pineal.
1 H 1730

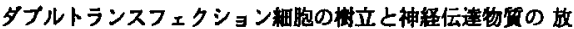
出棈權解明の試み

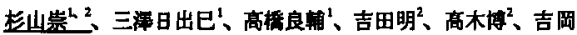
亭 $^{2}{ }^{1}$ 東京都神経研・神経学 ${ }^{2}$ 早稆田大学・人间科学部

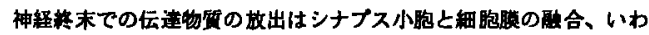
ゆる閉口放出によると考えられているか゚、シナブスの形堅は微小かつ愎

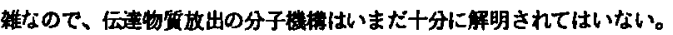

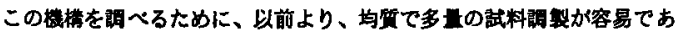

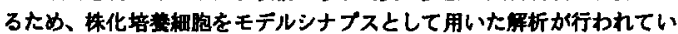

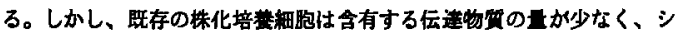
ナブス小盷の数も少ないため、成慗したシナブス機能を解析することは

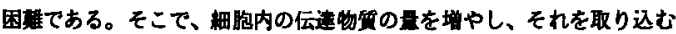
シナプス小胞の数を增やすことにより、より成䑨したプレシナブス機能 に近い能力を有する培細胞系の橵立を詰みた。

これまでに、伝造物得の一つであるアセチルコリン (ACh) や、シ ナブス小胞をそれそれ增加している湅䀛株の轱告がある。これらは、コ リンアセチル転移䁖素（ChAT） やシナプシンIbの进伝子を強制発現さ せて得られている。従って、この二つの正伝子を同時に発現させれば目 的とする湅盷㧣加得られる可能性が高い。

そこで我なは、ChAT道伝子を強力なプロモーターでおるHuman Elongation Factorのプロモーターを持つ発現ベクターに組み込み、ネオマ イシン酎性運伝子と共にNG108-15細盷へトランスフェクトした。G418

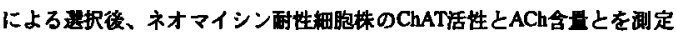
し、最もACh含量の高い耕䑦株を造んだ。この緗胞はトランスフェクト 前の耕胞に比へ、ACh含帛が約20倍に上舁していた。次に、同しプロモ

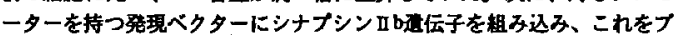
ラストサイシン婻性远伝子と共にChAT発現湅盷株へトランスフェクトし

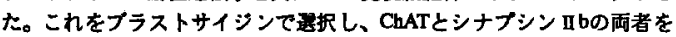
高度に発現すろダブルトランスフェクション細胞㧣を榯立した。

現在、この細胞株がダブルトランスフェクションによってどの棣な

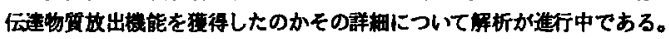

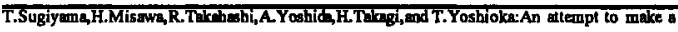
cell line which express ChAT and Synapsin Ibb genes.

111045

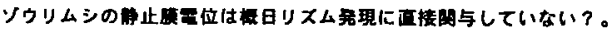

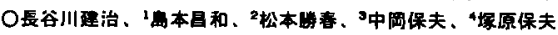

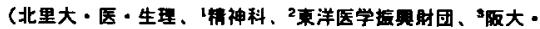
磷工・生物工、“楅北大・院、“理研フォトダイシックス)

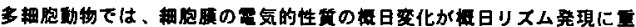
震な役揢を果たしている、とする考え方がる。

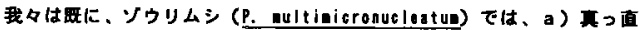

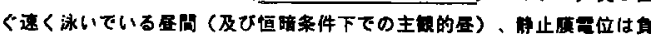

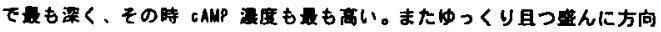

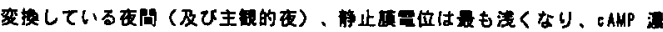

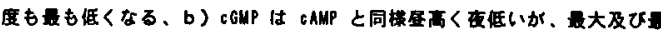
小に造する時到が CAMP より数時间早い、しかしc) CAMP/CGMP 比は昼高

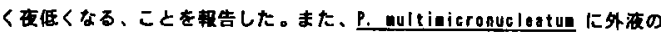

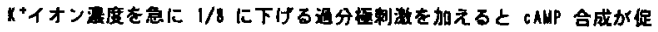

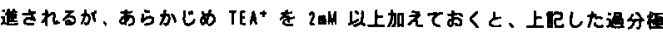

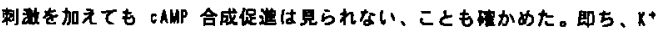
イオンの稩炮外流出と $\mathrm{AAMP}$ 合成が TEA で同時に阻赛される。

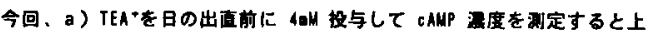

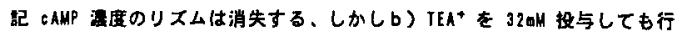
助リスムは消失しない、またc) $100 \mu \mathrm{M} の \mathrm{CdCl}_{2}$ 岸独投与ては行勘リス

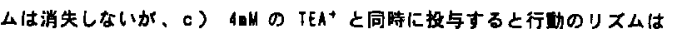
はっきりしなくなる、ことを破賽した。今回の眼給果は、ソウリムシて

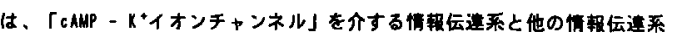

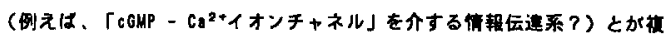

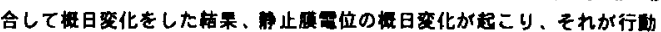
の蜼日リスムに反映されている可能性を示皮する。

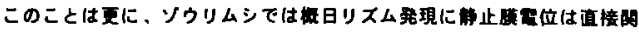
与していないことを示㖫するものでろう。

K. Hesegaws, M. Shimanoto, K. Hetuaoto, Y. Hakaoke, Y, Tsukahara: Rosting nobrone potential might bo not involved in circadian clock systen in Paraneciun. 
1 I 1100

離散型化学振動子系の同調現象

岡部医雄、“清口理子、坂本文隆、宮川蜸治 （福大理、“九大総理工）

結合ベルーソフ・ジャボチンスキー (BZ) 反心系は、細胞など 生体の自励振動系の同調現象のモデルとして、今日まて活発に研究さ れてきた。これらの研究では、主として、CSTR (Continuous Stirred Tank Reacter)が用いられている。ところで生体系の同調現 象はもっとミクロなスケールで起きており、この意味でミクロンサイ

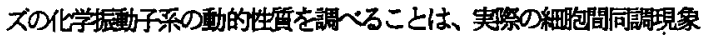
の理解を深功えで有意義なことでる。本研究ては Maselko et al.のBZ反庈系を本にして、BZ反店溶液に、触某としてフェロイン

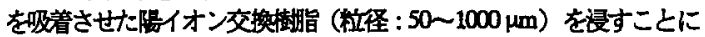

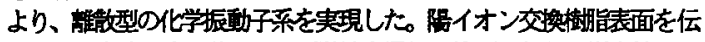

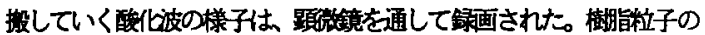
尝能は その周りの $3 \times 3$ 值のピクセルの故度を平均して得られた。

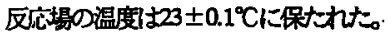

結果 : 図は、柆子の中心部で光強度の時間変化を表しており、現 システムが

ミクロンサイ スの振輅子系

と見なせるこ

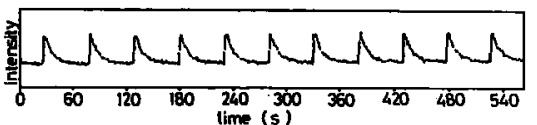

とを示している。粒子はそれそれ店有の根效を持っており、それは

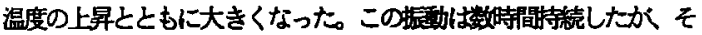

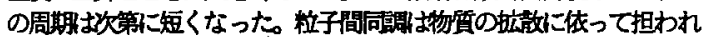
ており、それか定きる柆子間距雔に、臨界值力存在することが分かっ

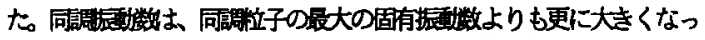
たが どの柆子がペースメーカーになるが不定であった。それは、 各々の同期持の位相に依存しているように思える。一旦同調すると、 外部柬游によって乱されても、或る時間後には同期を回復した。 T. Okabe, M. Mizoguchi, F. Sakamoto and K. Miyakawa: Synchronization among the discrete chemical oscillators

\section{0}

$$
\text { カタラーセの非線形振動反応とその温度，pHの影響 }
$$
千菜大理 0 秀島武敏 井上貴雄

前回の年会において、半透䐎をはさみそれぞれのセルにカタラーゼと通

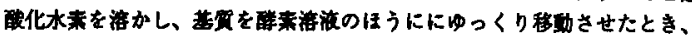

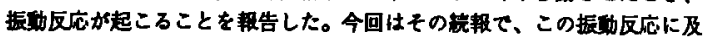

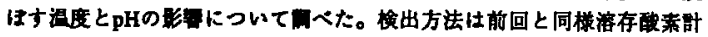

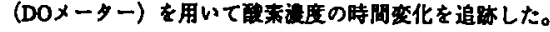

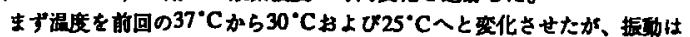
問题なく起こることがかかった。もの周期は約10分で榅度を下げても变化

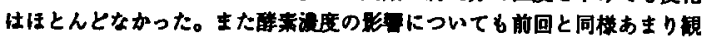

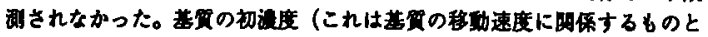
考えられる)についてい淇度の娍少とといに周期が長くなる㮌向にあるこ

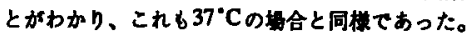

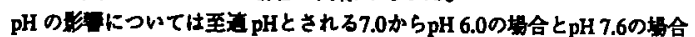

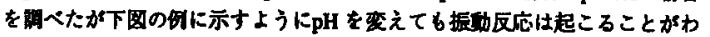
かった。

現在これらのテータをもとにこの振功反応の解析を行いつつある。

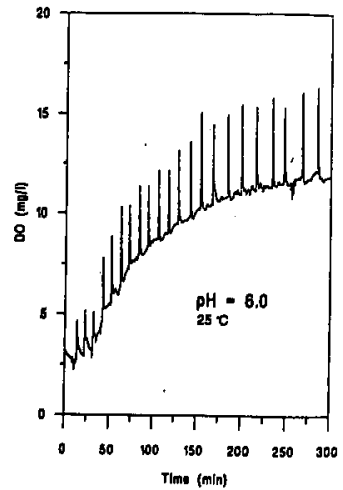

111115

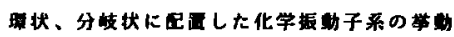

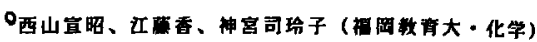

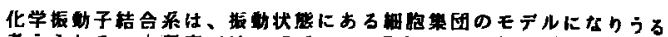

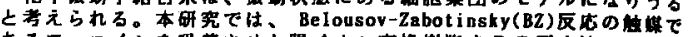

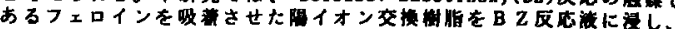

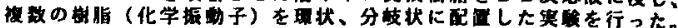

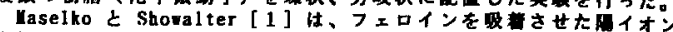

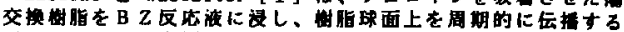
circular wave を既察している。circular raveが通逜するたひに、

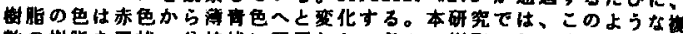

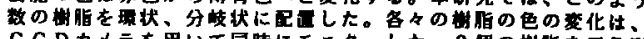

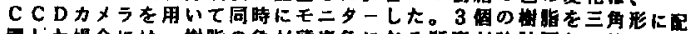

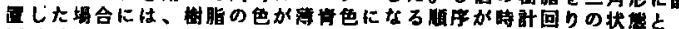

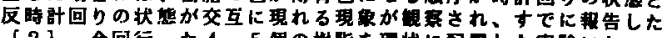

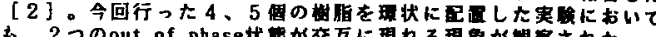

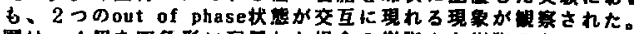

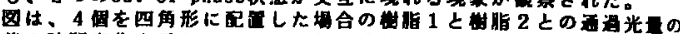

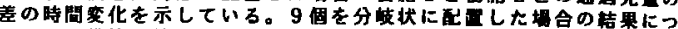
いては、典旗で述くる。

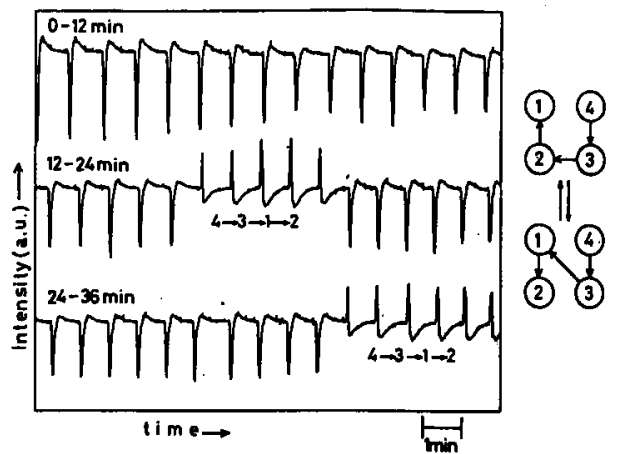

[ 1 ] J. Yaselko and K. Shoralter, Kature 339(1989)609. [ 2 ] N. Nishiyana and K. Eto, J. Chem. Phys. 100(1994)6977 N. Nishyana, R. Eto, R. Jingugi : Dynauical bebaviours of coupled chenical oscillators distributed spatially.

1 | 1145

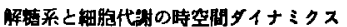

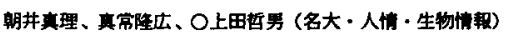

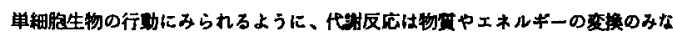

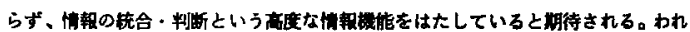

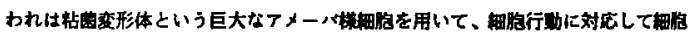

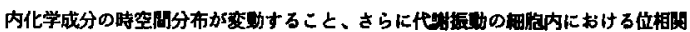

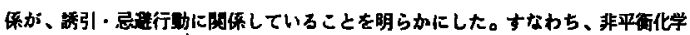

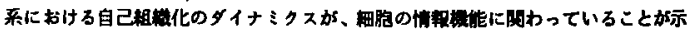

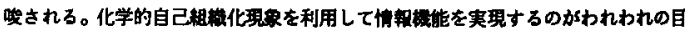
祭である。

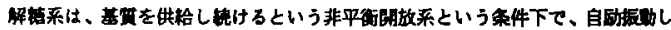

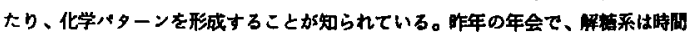

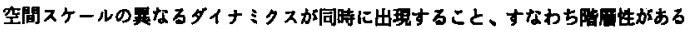

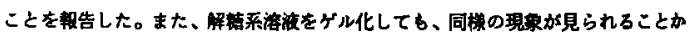

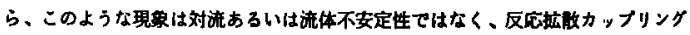

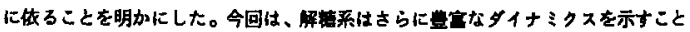

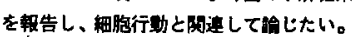

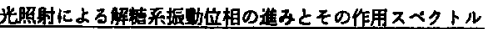

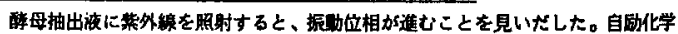

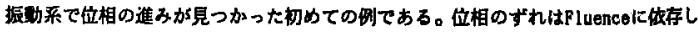
て大きくなった。作用スベクトルを束めると、400 nロおたりに小さなビークがあり、 300 nロ以下で大きいことがかかった。（基生研大型风ベ外其同利用による）

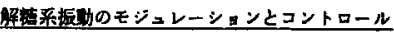

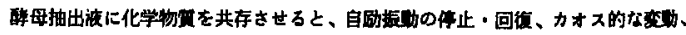

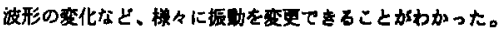


11200

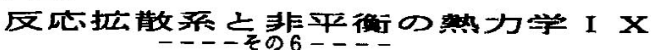

$$
\text { 京大・理大卓 }
$$

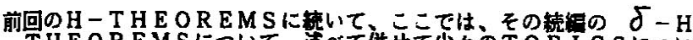
THEOREMSについて、速へて瓶せて少々のTOPIC Sについ (2)

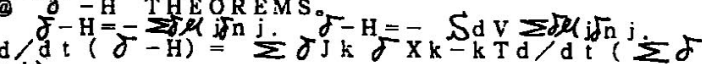
$\mathrm{d} / \mathrm{j} \mathrm{d}\left(\delta-\mathrm{H} \delta_{\mathrm{j}} \mathrm{S} \mathrm{dV} \geq \delta_{\mathrm{Jk}} \delta \mathrm{xk}-\mathrm{kTd} / \mathrm{dt}\right.$

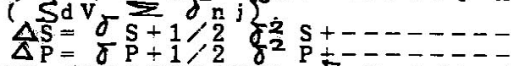

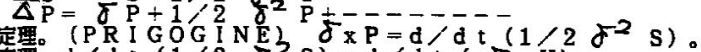

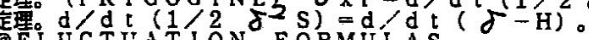
@LUCTUATION FORMULAS。

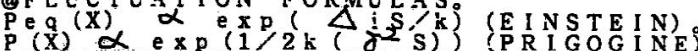

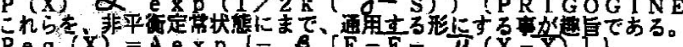
$\mathrm{P}$ e q $\left.(\mathrm{X})=\mathrm{A}_{\mathrm{r}} \mathrm{x} \mathrm{p}\left(-\frac{\beta}{\mu}\right)[\overline{\mathrm{F}}-\overline{\mathrm{F}}-\overline{\mathrm{X}}) \bar{\mu}(\mathrm{X}-\mathrm{X})\right]$

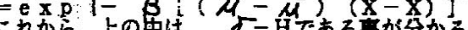

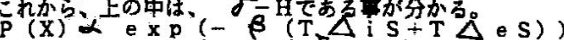

X) $\alpha$ exp $(-\beta(\mathrm{T}, \Delta \mathrm{i} s+\mathrm{s}$

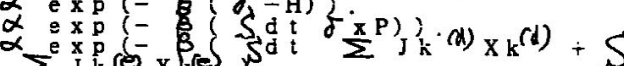
j :

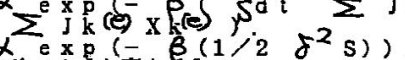

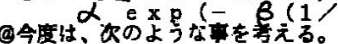

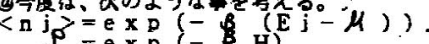

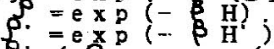

o. $=\mathrm{e} \mathrm{P}=\mathrm{x} \mathrm{H}\left(-\mathrm{B}_{\mathrm{d}} \mathrm{H}\right)$

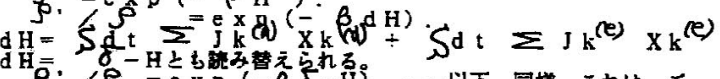

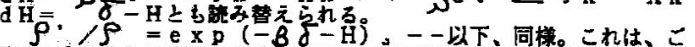

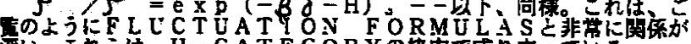

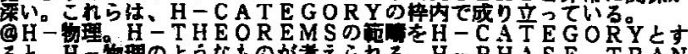

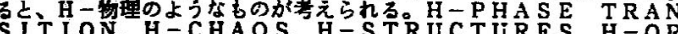
SITION. H-CHAOS. H-STRUCTURES, H-OR DERED S TATES, - - $----e$ t c

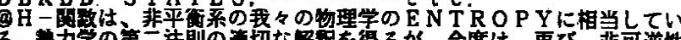

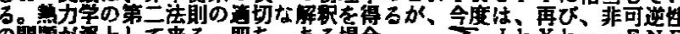

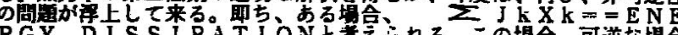

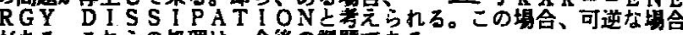
がある。これらの処理仕、今啳の課閶でちる。

\section{1 | 1415}

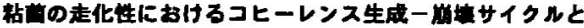

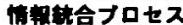

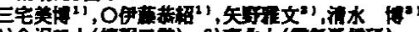

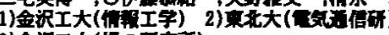

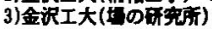

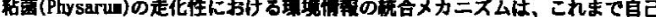

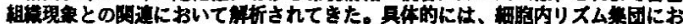

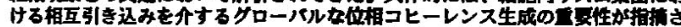

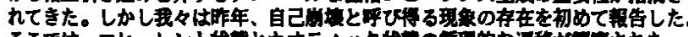

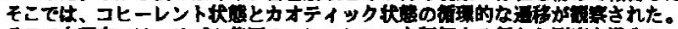

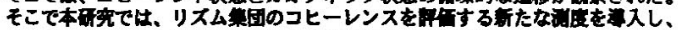

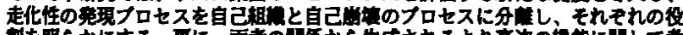

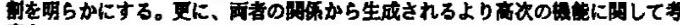
需方了。

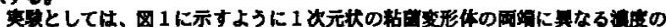

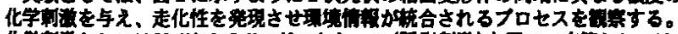

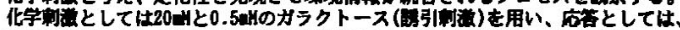

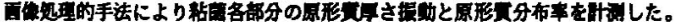

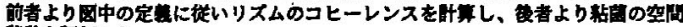

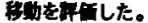

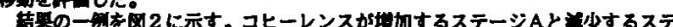

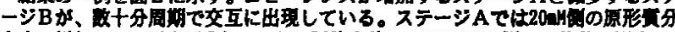

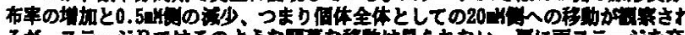

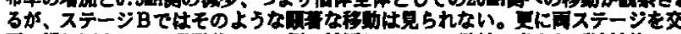

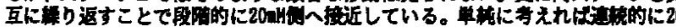

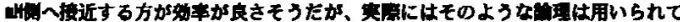

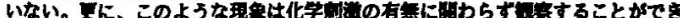

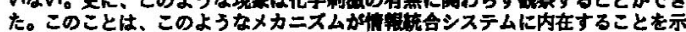
た。このこた。
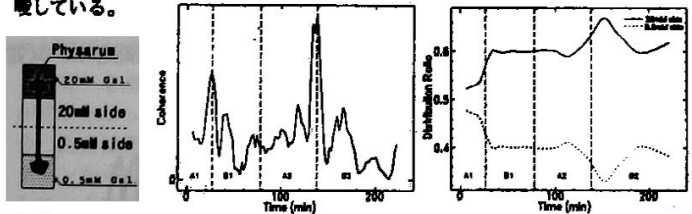

1 Shimulation condifition

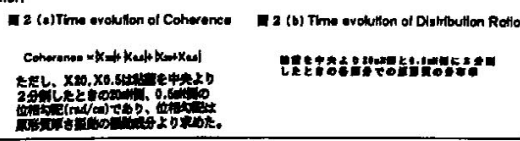

Y.Miyake,Y.Ito, H. Yano,H.Sinizu:Organization-disorganization cycle and infornation integration process in chemotaxis of Physarun
$1 \mid 1400$

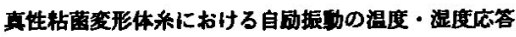

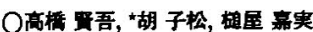

（東工大·生命理工・生体機棈, “果工大・理・応用物理）

真性粘菌変形体は変形体秝が利状に結合し、二次元的に広がった形状を している。この変形体は神経系を持たないか、倳々な局所剩激に対し全体

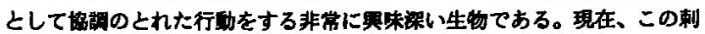
激一応答反応を、仮想的抺振動子ユニットか 2 次元的に結合した結合振動 子系のダイナミクスとして唭明するという㭗っな樲みがなされている。我々 はこの振助子ユニットとしての変形体系それ自身のダイナミクスを解明す ることを目的としている。

变形体から变形体系を切り出し荷重をかけて吊すと、绪直方向に収缩 ・

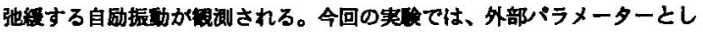

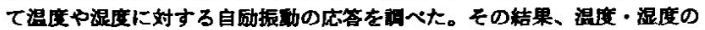
変化に対し、振勒周期が強い依存性を持つことが分かった。更に、この波 形を収蝡遇程と伸長造程とに分けて献へると、各々の遇程の温度・湿度要

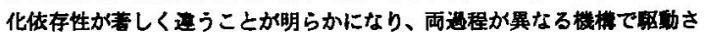
れているという知見を得た。

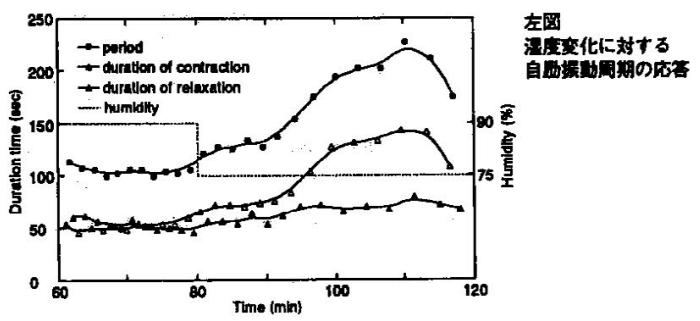

K. Takahashi, Z. Hu and Y. Tsuchiya: Resposes of self-excited oscillation of Physarum polycephalum strand to changes of temperature and humidity.

1 | 1430

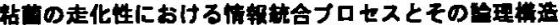 三宅舟傅"

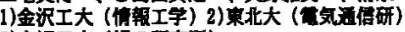 3)金沢土大 (}

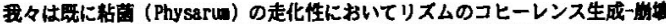

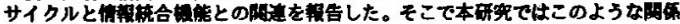

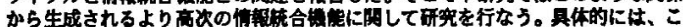

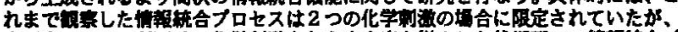

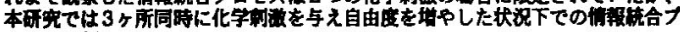
ロセスを同へる。

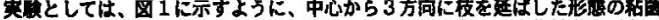

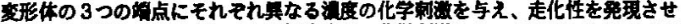

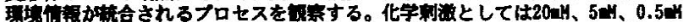

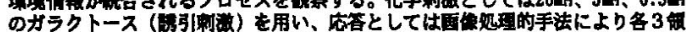

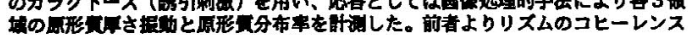

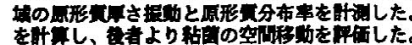

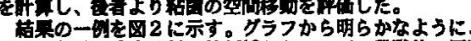

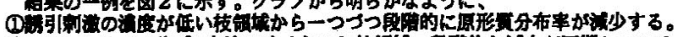

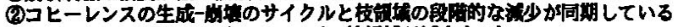

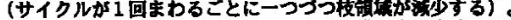

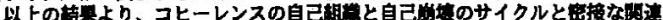

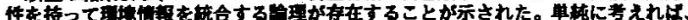

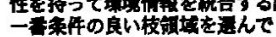
他の技をすく引つ込めてしまえ

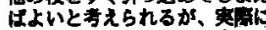

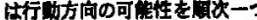
うつ沙させるという的の 㬜用いている。国在、このよ

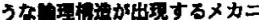
スムを实的に棜している。

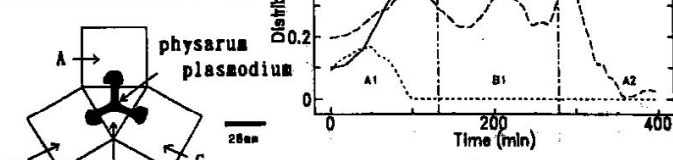

B

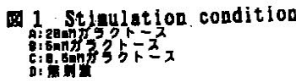

2 Time evolution of Distribution Ratio

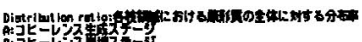

Y.Miyake, M.Shinada, K. Yano,H.Shinizu: Inforation integration process and its logical structure in chemotaxis of Physarum 
111445

Self-oscillation in nerve with a dissipative structure

Kotaro Shirane, Takayuki Tokimoto and Hiroyuki Kushibe* Osaka City Univ. Med. Sch. and Faculty of Eng.

The excitation in nerve that forms a dissipative structure with the resting membrane potential (an equilibrium state) occurs on the equilibrium space for a cusp catastrophe. The space is given by $n^{3}+a n+b=0$ deduced from a chemical network model 1,2 which is applied to Leuchtag's ferroelectric hypothesis for Na channels, where $\Pi$ corresponds to the membrane potential, and a and $b$ are control parameters related to dipole-dipole and dipole-ion interactions, respectively. With modified Zeemen's formulas for the movements of a and $b: \dot{a}=$ $-2(a+\eta)$ and $\dot{b}=-a-1-f+S_{B}(\tau, t)^{1,2}$, the natural frequency of the self-oscillation can be computed by the above equations. When the membrane is disturbed by a periodical $\mathrm{Na}$ current ( $S=I_{0}+I_{1}$ cossut) with the natural frequency or the near one, the self-oscillation of $n$ occurs through a phase transition of the membrane because the trajectory of $a$ and $\dot{b}$ describes a stable limit cycle on the control (a-b) plane with 8 - 1. The stimulus intensity $S$ is a parameter that characterizes the phase transition or Hopf bifurcation. The calculation of $\dot{a}$ and $\dot{b}$ Indicates that the limit cycle arises in a region as shown in figure, where $S_{1}$ is the lowest limit and $S_{h}$ is the highest one. When $S>S_{h}$, the excitation does not occur because the stable point transfers to a point $(s>0)$ on the space. Both $S_{1}$ and $S_{h}$ are inverted bifurcation points.

1. Shirane et al., Ferroelectrics, 141,297,1993. 2. Tokimoto \& Shirane, ibid, 146,73,1993.

\section{5}

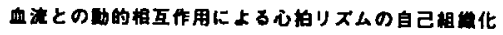

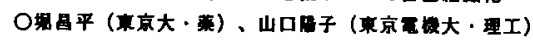

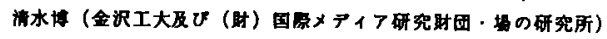

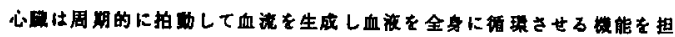

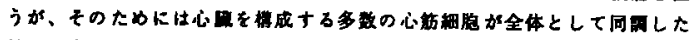

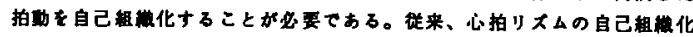

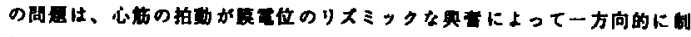

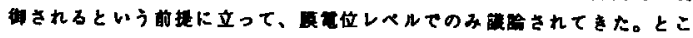

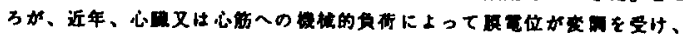

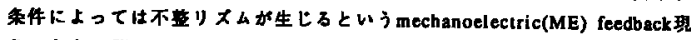

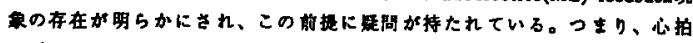
リスムは血流を生成すると同時に生した血礼により变化することになる。

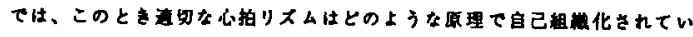

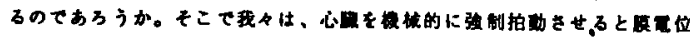

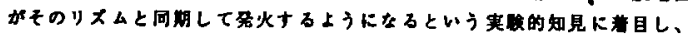

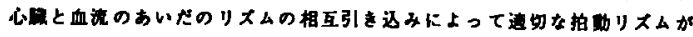

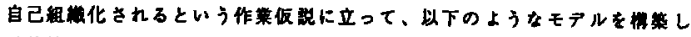

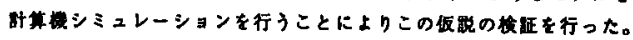

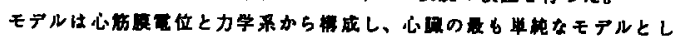

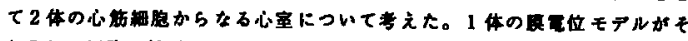

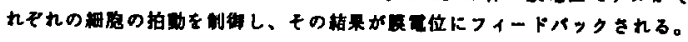
セの結果、それぞれにME feedbackを入れることによって、每相肉に拍物

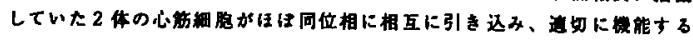

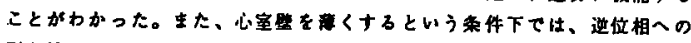

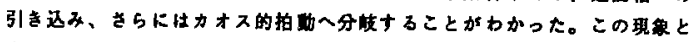

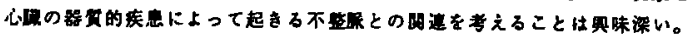

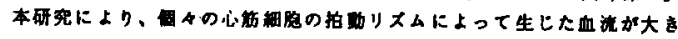

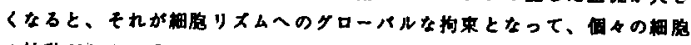

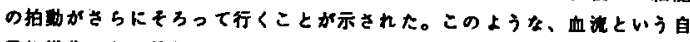

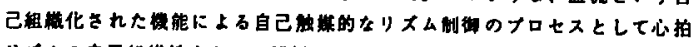

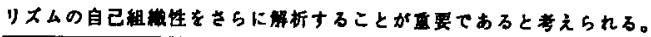
S.Hori. Y.Yamaguchi \& H.Shimizu: Self-organization of synchronized shythm of the heart through dynamical interaction with the blood flow.
111500

不整豚のデジタル情䐚

O白石彰锗（白石医院）

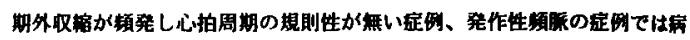

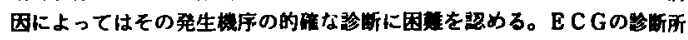
見はその被形によるのであるから、アナログ情艮として平四すへき物であ る。此の波形情報によって不整周期を示す E C Gと心エコー同期 E C Gと

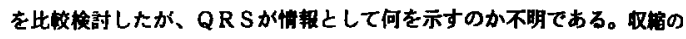

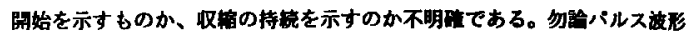
であるから収培はQR S とすれば充分であるが、これは情䢁悬の点で不充

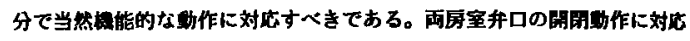
するデジタル信号をRとする事を梌討したが、R波は年口のONOF F h

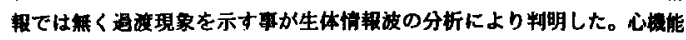
のデシタル情辄化をするためにそのタイムチャートを作成したが、羊口部 の機能はデシタル信号であるが、EＣＧのバラメタはアナログ情船として の信号であるからタイムチャートに対応する迨合性渎い。このタイムチ

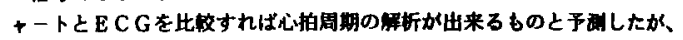

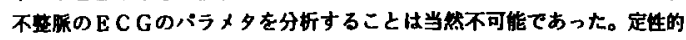

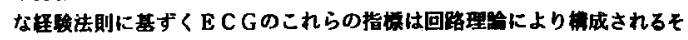

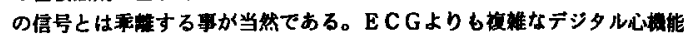

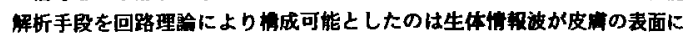
存在するからである。それを解析する事により不整然の心拍周期が何を意 昧するのか、そのE C G 波形か意味するのは何かを分断する亭がでる。

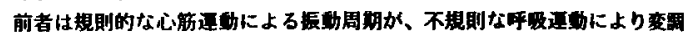
され不規則な周期通釛が生体表面に発生することを示す。ECG波形と生

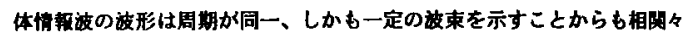
俰がることは明らかである。不整愿の E C G波形はデジタル房号として

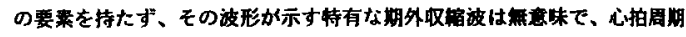

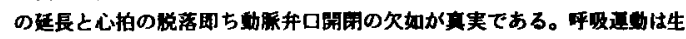

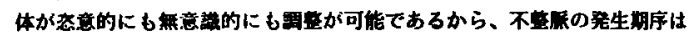
当然心融外の病理学的モーメントによると考えることが可能である。

A. SHIRAISHI : DIGITAL INPORMATION OP ARRHYTIDIIA

1 | 1530

アガロース $/ \mathrm{NaCl}$ 系ゲル中に保持した トリオレイン含浸膜の自堛発振

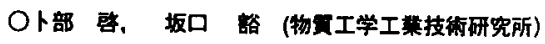

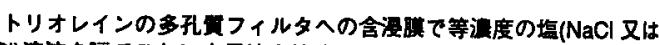

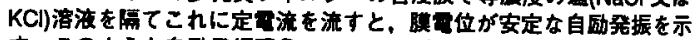
す。このような自励発振現象のセンシング，倍号卒换なと各方面への

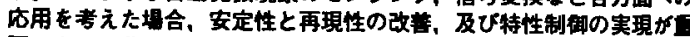

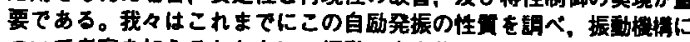

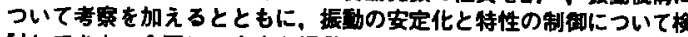
村してきた。今回は、安定な振酒の発生が可能な状能を䊒持しつつ, 㙋両側からイオンを供垥する役剖を果たしている涴液部分を固定化し て系を安定化させる目的で, 㬴而側の塩溶流をゲル化して実确を行っ たので、その結果を報告する。

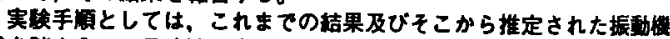

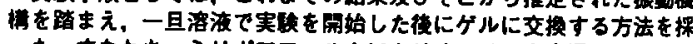
つた。すなわち、ミリポアフィルタにトリオレインを含漫させて2 㑑 のアクリルセル同に挟み、まず両側のセルに $0.5 \mathrm{M} \mathrm{NaCl}$ 㴼液を满たし、

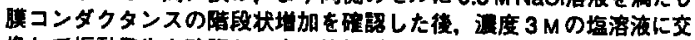

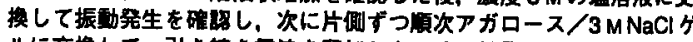
ルに交换して、引を繶き量流を明加した。その結果，ゲルに交换した 後にも䀧のベースコンダクタンスはほほ交換前と同程度のレベルを示

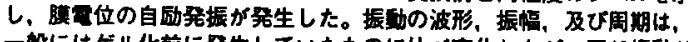

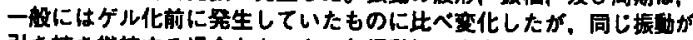

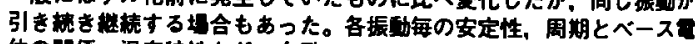
位の閂保，渴度特性力と，自励

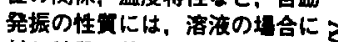
对し特段の差は見られず。䀧両 側の潧液部分をゲルに交换して 固定化しても膜は同样に振动可 能な状晿を維持することが成ら かとなった。フィルタのれに. はトリオレインとともにゲル化息

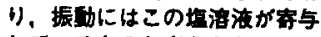
しているものと宩えられる。

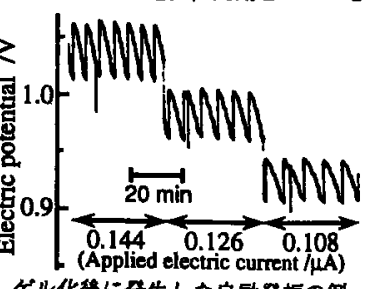

K. Urabe, H. Sakaguchi : Self-oscillations of triolein impregnated membrane between $\mathrm{NaCl}$ Agarose gel. 
1 | 1545

人工脂汻膜の味物诈への応答の機構と動特性 ○野村和生. 都甲 潔 ${ }^{+}$(九州大: 理・化学, 十九州大・工・電子工学)

ジオレイルリン酸をメンフランフィルターに含浸 させた脂質膜（DOPH膜）は，5つの基本味物睤（酸 味，塩味、苦味、甘味および，うま味)に対しそれ それ異なった応答特性を示すことが定常状態の膜電 位と膜電刑度及び動的な応答の測定結果から明らか にされている。また，応答のいき值も生体系に近い 值である.

解離基をイオン交換サイトとして持つ荷電膜と電 解質溶液の相境界ではドナン電位が発生し，膜内搪 散電位とドナン電位の和が膜電位として観測される。 本研究では，DOPH膜の定常状狙の膜電位と膜電茅度 の味物所浱度依存性についての実験結果を荷電膜の 膜理論に基ついて解析し、味物所の膜/水溶液間の 分町係数，味物啠之脂買の解離基との複合体生成反 応の平街定数及び膜内の移動度が応答特性をどの様 に支配しているかを検討した．水相は酸味物啠しし てHCl，塩味物質としてNaCl，苦味物質としてキ二 一ネ，甘味物啠としてショ糖が添加されたKCl水溶 液である.さらにそれそれの味物質が添扣された系 での膜電位に対するドナン電位と膜内搪散電位各々 の寄与を明らかにし，それに基ついて過度的な応答 の特性について検討した．

K. Nomura and K. Toko: Dynamic Characteristic and Mechanism of Responce of Artificial Lipid Membrane to Taste Substances

\section{1 | 1615}

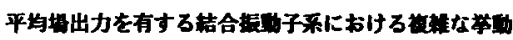

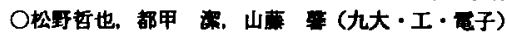

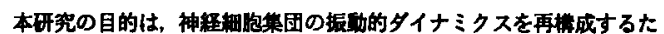

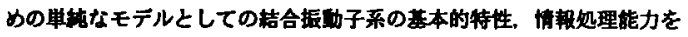
明らかにすることである。

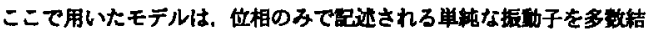

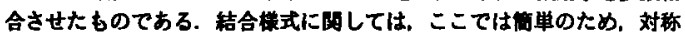
結合とした. また，出力ユニットとしての据动子集団においては，それぞ

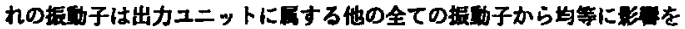

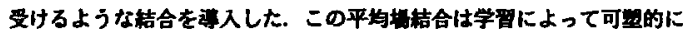
変化する通常の結合に重量される. さらに，出力ユニットの据動子の集

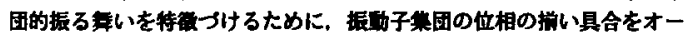
ターバラメータとして探用した. ここでオオタターバラメータの值その ちのを出力とし. ある入力位相バターンに対して任意の指定された值を 出力させるための正当な学習アルコリスムを尃入した.

結果として，弯入された学翼アルゴリスムは指定された入出力阙保を 実现することが解析的に，また数嗦的に示された. さらに，未学習の位 相バターン（学習した位相パターンに対して十分㬵倾度が低い）を系に

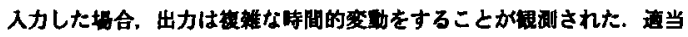

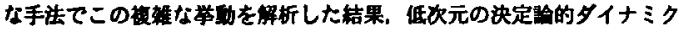

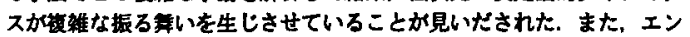

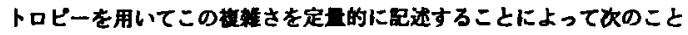

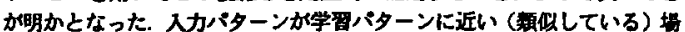
合、出力は学習させた定常值に近い值をとった，入カパターンを学習バ

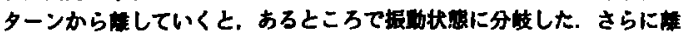

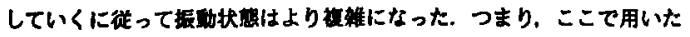
結合振助子系は. 入かバターンが既知の（学習した）バターンに対して どの程度器なっているかを蜼なタイナミクスにより表現する能力を有 することがかかった.

T. Matsuno, K. Toko, K. Yamafuji: Complex behaviour of a local mean field as an output of coupled-oscillator system.
$1 / 1600$

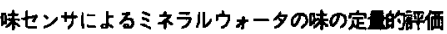

○近莱 美希，饭山悟*，江崎秀*，都甲樑**

(近幾大 · 九州短大，*近畿大 · 九州工，**九州大 · 工)

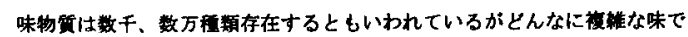
も5基本味のそれぞれの強さでもって私たちは味を感してる。特に食品工莱 界では紫品の品筫管理の特性を模查することがしばしばあるのだが、人間の 感賞で整造工程を一定にすることは不可能で、味センサはこういた人間に よる官能娭查の禣助や代行を第 1 の目的として開発された。このセンサは8

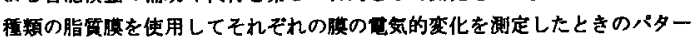

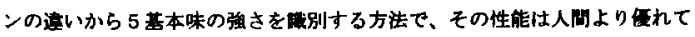
いる。

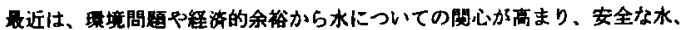
おいしい水、康によい水なとをを求める俱向にある。一方、水は品品多く含 まれ、食品の紫造過程でも使用される努合むあることから水は食品のまな成 分と捉え、木の重要性が䜅捕されてきた。さらに私たちは水について身近な しのでありながらも水の品梊についてはあいまいな情埌しか手に入らない。

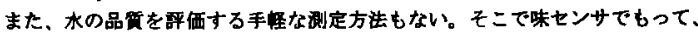

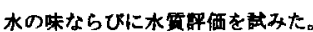

サンプルの水は硬拣 1 から734までのミネラルウォータ20数理を逼ひ、こ れらの水に対して味センサ测定し、主成分分析を行った。その結果、即定基

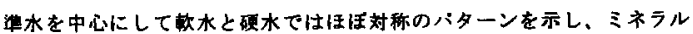
ウォータの硕库が大きいほど、第1主成分は大きくなることからかルシウム

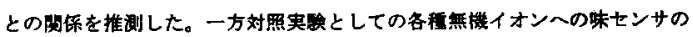

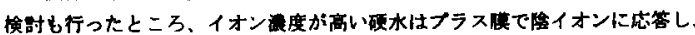

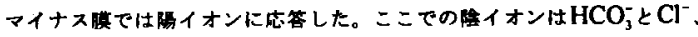

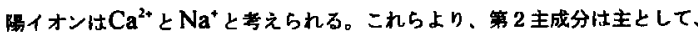
$\mathrm{Ca}^{2+}$ とHCO;のバランスに相当していると推测される。この分析マッブを

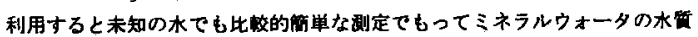
を知ることが出来る。

M.Chikaba, S.liyama S.Ezaki,K.Toko : Quantitative Taste Evaluation of Mineral Water with Taste Sensor.

\section{0}

$$
\begin{aligned}
& \text { オープンカオスによる稩胞分化 } \\
& \text { ○金子韧陵十四方括也 } \\
& \text { (柬大攻表，十阪大I) }
\end{aligned}
$$

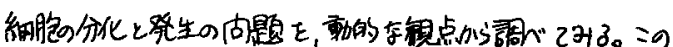

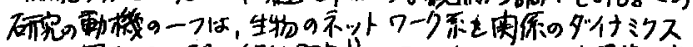

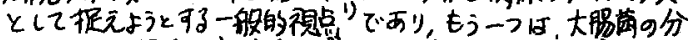

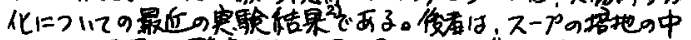

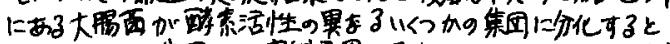

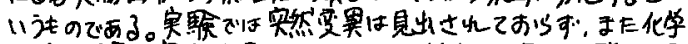

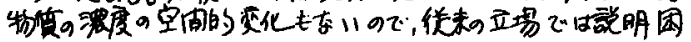
像住である。

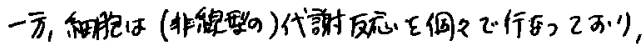

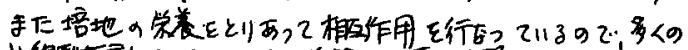

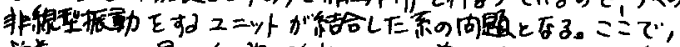

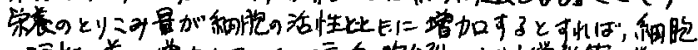

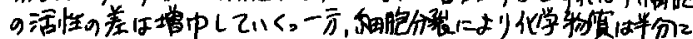

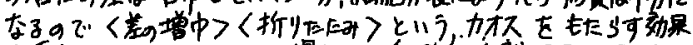

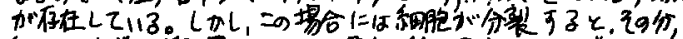

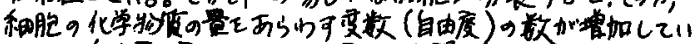

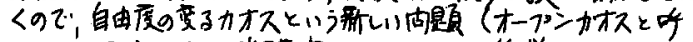

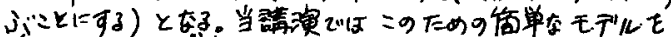

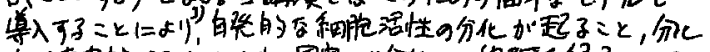

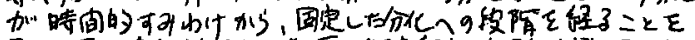

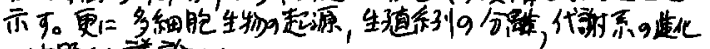

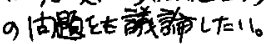

1) K. Kaneko Physica 4ID (1990)137; "Relevence of Dimanic Clustering in Bidogical Networks", Phyorca D(1994) in press (Avard) 2) E.Ko, T. Yomo, I. Urabe, "Driamic Clustering of Bacterial Population" "Physica D'(1994), in press

3) Kr Kaveko and T. Yomo, "Coll Drisim, Differentiation, and

Dynamie Clustering", Physica. D(11944), in press 
$1 \mid 1645$

\section{再識の非局所作用と負のエントロピー としての性質}

O頼戸 明、山本竜隆、久光 正（昭和大・医・第一生理）

エックルス（Eccles）は舴神と物霍は別であり、心は爫の物理化

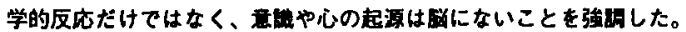
しかしながらこのような見解は梪めて少数であり、大多数の研究者は、

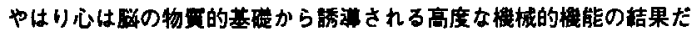
と考えている。

我々は悉讜、心、あるいは神といったものの其の姿を模討するた

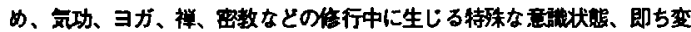

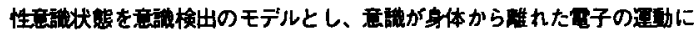
铛を与えるかどうかを検㣙した。

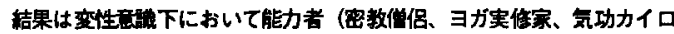

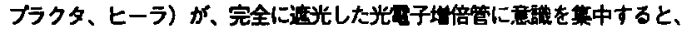

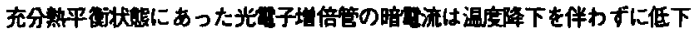

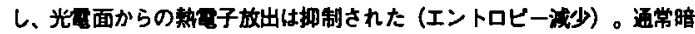
国流は温度を下げなけれは低下しない。もし今回の暗事流の低下分を温度 降下に换算すると、あたかも温度が3゚〜〜゙C降下したと等しい反応になる。

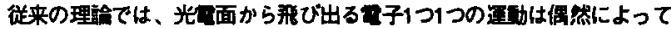
支束されているが、その飛び出すの子全体の逜动の平均值は温度によって

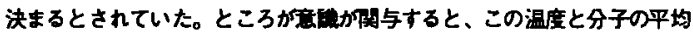

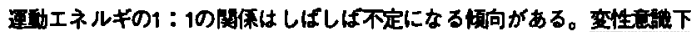

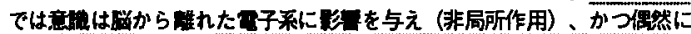
よって支军されているて子の軍功に、ある目的をもった制御を行う。この

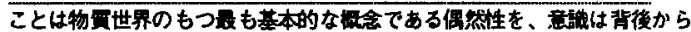

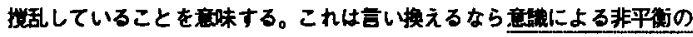
生成であり、即ち貝のエントロビーの得である。

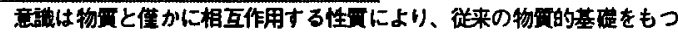

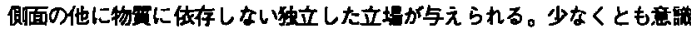
や心にはそれだけの基かな可能性が楂んでいるが、研究者は苦通、心をんス ホンスとして报っているので、まだその一部しか㫬间見ていないだけである。

A SETO, T. YAMAMOTO, T. HISAMITSU : Properties of Consciousness as Nonlocal Action and Negative Entropy.

\section{$1 \mathrm{~J} 0945$}

COSMOS90による变性温度の正確な予測と解析

(蛋白工学研) 录蕉 稳

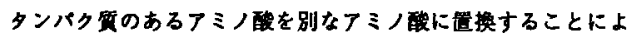
って、変性温度が㖽著に变化することが知られている。この変性温度

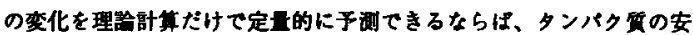

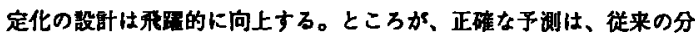

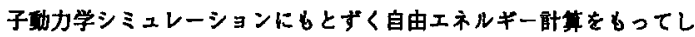
ても計筆粗度が不十分であり不可能であるとされてきた。

現在の分子功力学シミュレーションにもとずく自由エネルギー

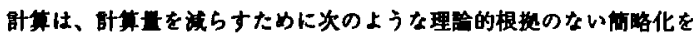
行なっており倌賴性に問鬽がある。（1）タンパク暂の興味のあるー 部分にのみ水分子を付加している。（2）原子无萑閍のクーロン相互 作用を、10ー15オングストロームでカットオフしている。（3） タンパク贸の特定の棕城（侸立ば活性部位）の外にある原子を、初期 搆造（X線榙晶棬造）に固定し系の自由度を诚らしている。

最近管者仕、数万原子加なる系のクーロン相互作用を、高速 に精度良く斯算する独自の方法（PPPC法）を開発した。また、こ の方法を組み込んだ分子動力学シミュレーションのプログラム(COSM

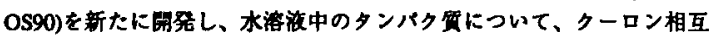
作用をカットオフせずに゙すぐての原子の遇動をシミュレートすること を可能にした（文献參照）。

筆者らは、COSMOS90を用いてRNaseHIの 4 つの交異体の资性温 度の予测を行なった。その桔果、実験值を非常に良い精度（1度以内 の莩い)て予测することに初めて成功した。また、自由エネルギーの 成分を分析をすることによって、4つの変罢体のそれぞれの安定化

（あるいは不安定化）の要因を明らかたした。

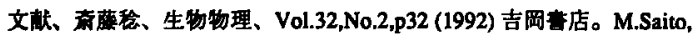
Molecular Simulation, 8, 321 (1992).

M.Saito, Accurate prediction and analysis of transition temperatures of mutant proteins using COSMOS 90 .
1 J 0930

蛋白質の折りたたみのエントロピーに関する考察 吉江 尚子（東工大·生命理工・生体分子）

蛋白質の折りたたまれた(native state)の安定性は、第力学的に は二つの要素によって決定される。即ち、アミノ酸残基間の相 互作用とコンホメーションのエントロピーである。このうち、 アミノ酸残基間の相互作用については多くの研究がなされてい るが、エントロビーに関する考察はほとんどなされていない。 本研究は、単純なモデル鎖を用いて、このコンホメーションの エントロビーに閲る知見を得ることを目的とする。

ここでは、モデル鎖としてはランダムフライト鎖を考える。 この鎖のあるコンホメーションで残基が空間的に嚾接している 状態をコンタクトと呼占。「䍻中のある特定の 2 残基がコンタ クトしている」という条件を与えるとコンホメーションの自由 度は減少する。このようなコンタクトを橧数与えたときの自由 度の減少をエントロピーとして評侕し、このエントロビーのコ ンタクト数や租み合わせに対する依存性を考察した。

特別な二次粠造を持たないランダムなコンホメーションの場 合には、エントロビーはコンタクト数に対して直線的に增加す る事がわかった。即ち、コンタクト1個当たりのエントロビー 損は一定である。この直線性はコンタクト数が 10 图以上の場 合に成り立つが、それ以下の場合には成り立たず、コンタクト 当たりのエントロビーは大きくなるようである。また、へリッ クスやシート状の二次棌造を持つようなコンホメーションの場 合にはエントロピーはランダムなものよりも大きくなることが わかった。

N.Yoshie : Conformational Entoropy of Protein Folding

$1 \mathrm{~J} 1000$

RN a s e H IのV 74 A変異体の自由エネルギー摂 動法による熟安定性の解析

O谷村隆次·杽藤 稳 (蛋白工学研)

大腸菌由来の Ribonuclease $\mathrm{H}$ ( $\mathrm{RN}$ axe HI, 155アミノ酸残基）の Va 174 をA 1 aにアミノ酸置換したV74 A変異体は、 野性型に比へその熟変性温度が12. $7^{\circ}$ C 低下し、熱に对し て不安定になる。 " 野性型 RNaseHのX楾結晶椑造によると、 V a I 74 はへリックス中に位目し、疎水性のコアを形成し ており、その側銧は蛋白質内部に埋しれている。 ${ }^{2)}$ すなわ ち、V 74 Aは、野性型に比べ、コア内部のメチル基 2つを 欠失している。：このアミノ酸相換にともなう熟安定性の変化 の原因を明かにするため、COSMOS $90{ }^{31}$ を用いて分子 動力学シミュレーション、自由エネルギー摂動法による解析

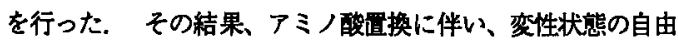
エネルギーが減少することがわかった。 この㚆性状態の自由 エネルギーの減少は、V 74 Aの天然状態を相对的に不安定 化することに寄与している。 また、天然状態のシミュレーショ ンではアミノ酸置換に伴ない、VaI（A１ a）７4 周辺に わいて大きな構造变化か認められた。

1) Ishikawa, K., et.al., Biochemistry 32,6171-6178 (1993).

2) Katayanagi, K., et. al., J.Mol.Biol. 223,1029-1052 (1992).

3) Saito, M., Molecular Simulation 8.321-333(1992)

R. Tanimura, M. Saito :

A free energy perturbation study of RNase HI V74A mutant. 
1 J 1015

タンバク政の FoldingとUnfoldingの Batmor

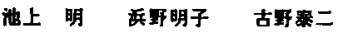

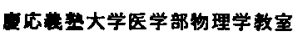

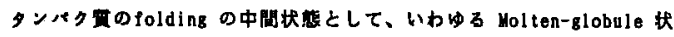

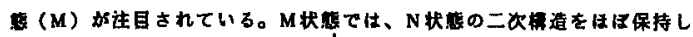

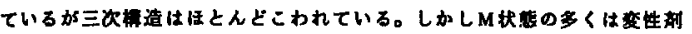

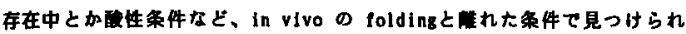
ている。我々仕昨年度、NとDの中間状照の热力学的安定性を、一股的な

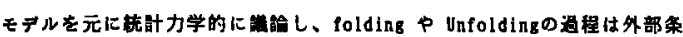

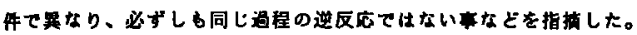

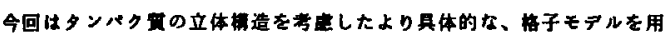

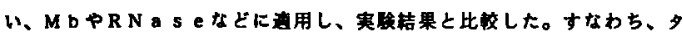

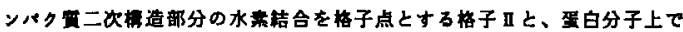

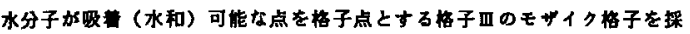

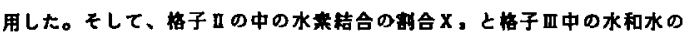

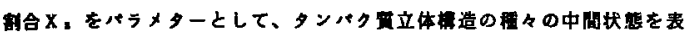
示し、自由エネルギーの侾計カ学的計英から安定な中間状意などを求かた。

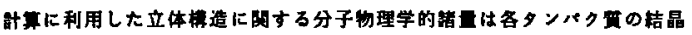

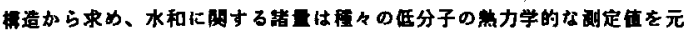
に大井らが覃析して求め大值を使用した。

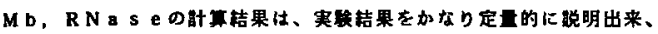

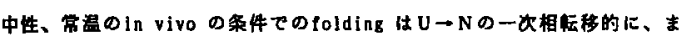
た中性高昷でのunfolding

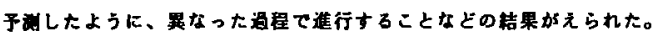

A. Ikegani. A. Hanano and T. Puruno : Statistical Thermodynanics of Protein Polding and Unfolding.

\section{$1 \mathrm{~J} 1045$}

\section{蛋白質の表面電位の計算と実験との比較}

高卓也，Antony S. Dimitrov"，Nikolai D. Denkov*; 水山国昭

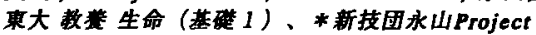

蛋白面の表面電位は、それを樓成する牫基の荷䉓状態と立体的な分 布、 $\mathrm{pH}$ して溶某のイオン強度（I）などで決まる。今回我々はフェ リチン分子の表面電位を計算し、対応する電位䁚定実鈋と此較した。

蛋白票の周りの電位の計算法として、侤電体モデルの数値解法を用 いた。この方法は承白西近傍の奄位の実雅值をよく就明するしのであ る1)。そして表面からデハイイ医權（ののルートに逆比例）だけ離れた面 で電位を平均するアルゴリスムを閒発し、ゼー夕電位を求めた。

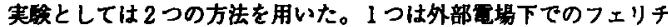
ン分子の易動度を恻定し、その值から計基する方法で、もう1つは光 敞乱の実駼から第 2 ビリアル保数を求め、球モデルから表面電荷密度 及びゼー夕電位を計鿓する手法22である。

以下の表に計算と実験結果（ホロフェリチン）を示す。電気易動度 加ら求めた值は摆差を多く合んでいるが、值の符号とオーダーは合っ ていることがわかる。さらに胘存性の計算を行い、より精度の高い アポフェリチンでの実䄸值（第 2 ビリアル係数から求めた）との比㜞 結果についてい発表するチ定である。

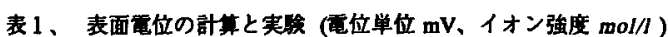

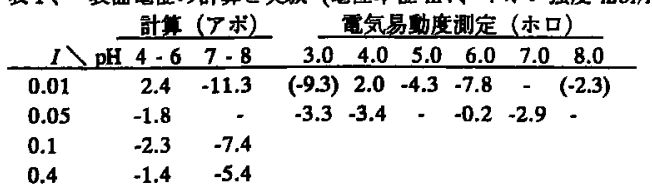

1) T. Takahashi et al., Biopolymers, 32, 897-909 (1992)

2) D. N. Petsev \& N. D. Denkov, J. Colloid. Interface. Sci., 149, 329-344 (1992)

T. Takahashi, A. S. Dimitrov, N. D. Denkov, K Nagayama: Calculations and Experiments of Protein Surface Electrostatic Potential
$1 \mathrm{~J} 1030$

分子動力学/自由エネルギー摂動法で計算され たアミノ酸間の水和の自由エネルギー差の検討 ○山乙教之、広野修一（北里大・莱）

【目的】Sharpらは、実験から求められたアミノ酸の水和 の自由エネルギー変化が過小評価されていることを理論 的に示し、その補正値を提示した。そして、実験値とコ ンピュータシミュレーションで得られた值との一致につ いて再評価する必要性を示唆した。そこて、我々は、分 子動力学/自由エネルギー撖動法によって求められたて ミノ酸間の水和の自由エネルギー差が、実験值と補正值 のどちらの值を再現しているのかを明らかにすることを 試みた。

【方法】計算には、分子動力学プログラムバッケーシ AMBER4.0を用い、各アミノ酸のN-アセチル- $N^{\prime}$ メチルル ミド体間の水和の自由エネルギー差を、分子動力学/自 由エネルギー攝動法により求めた。

【結果】各アミノ酸間の水和の自由エネルギー差の計算 值と実験値及び補正値とを比較した喆果、計算值と実験 值との相関は、相関保数；0.938、一次回淿式；実験值 $=$ $0.823 \times$ 計算値一 0.235 が得られた。また、計算値と補正 值との相関は、相関係数；0.987で、一次回㷌式；補正值 $=1.042 \times$ 計算值 -0.172 となった。従って、分子動力学 /自由エネルギー摄動法により求めた各てミノ酸間の水 和の自由エネルギー差はSharpらによる補正值を再現して いることがわかった。

Sharp et al., Biochemistry, 30, 9686 (1991).

N. Yamaotsu, S. Hirono : Free Energy Differences between Amino Acids Calculated by Free Energy Perturbation Method.

$1 \mathrm{~J} 1100$

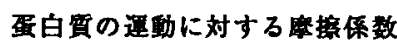

○北尾 彰朗、スティーナン ヘイワード、平田 文男、狠 信広 (京大・理・化学)

蛋白質のダイナミクスは、溶媒の水から様々な影蟋を受 ける。抬散係数や摩㨲保数は、これらの影謷を钼察するう えで重要な旦である。蛋白質分子全体の並進・回転㹡散保 数に网しては、実験的な值が知られており、オシーン・テ ンソルなどのハイドロダイナミックなモテルや|1|、分子動 力学計萛から得られた値|2|と比㜞されている。一方、我々 はこれまでに分子動力学嘼算によって得られた秥果に対し て、ランジュヴァン方程式を用いたモテルを通用し、ビコ 秒オーダーの連い動きの感じる摩㨲係数をBPTI䦎して 計算した[3]。その桔果、これらの度瑏保数は、モードに依 らずほほ一定と見なせることが明らかになった。年会では、 このような結果が得られた原因を調べるため、各原子に対 する摩揞係数 - 分子全体の並進・回転に対する糜揞係数 . モードに対する摩揞保数を比㜞・検討する。 【文献】

[1|R.M. Venable, R.W. Pastor, Biopolymers, 27, 1001 (1988) [2]P.E. Smith, W.F. van Gunsteren, J. Mol. Biol. 236, 629 (1994)

[3]S. Hayward, A. Kitao, F. Hirata, N. Go, J. Mol. Biol. 234, 1207 (1993)

A. Kitao, S. Hayward, F. Hirata, N. Go : Friction coefficient for collective motion in a protein 
$1 \mathrm{~J} 1115$

TIMバレル中の $\beta$ シートのバッキング・シミュレーション

○長野希美、“長野晃三（東大·莱・物理分析、+都老人研 晴轰シミュレーション)

蛋白颀の構造予测を行う際に、三次槽造が郝告されている蛋白質と の相同性が高けれは、予测も比較的容易になってきています。しかし ながら、逆に相同性が低くても良く似た三次粠造、超二次棬造をとる 蛋白復し数多くあることが知られています。我々は、超二次棰造こと

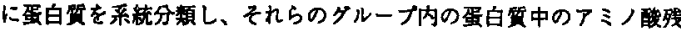

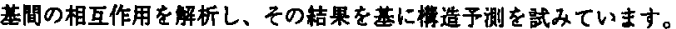

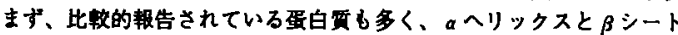
が規則的に並んでいるTIMバレルを对象にして、解析を行いました。 パレル構造は、主に $\beta$ シート間の水莱桔合、瑓水相互作用などによる 相互作用、 $a$ ヘリックス間の相互作用および $\alpha$ ヘリックスと $\beta$ シート 間の相互作用で出来上がっていると考えられ、特に $\beta$ シート閒のパッ キングは、この㩐造を形成する上で大きく寄与していると考え、この

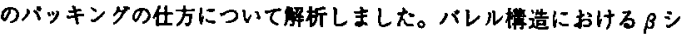
一トのアミノ酸即鎖は大きく分けて、バレルの内側と外即を向くこと がかかっているので、内即を向くアミ/䃌こと、および外㑡を向くも のことにそれぞれ並へ、シート内のアミノ酸およびシート間のアミ， 酸の位置関係について統計的解析を行いました。その結果、内㑚を向 くアミ/酸同士、外㑡を向くもの同士で、それぞれかなり高頻度で出 現するアミノ酸詨を見つけました。こうした桔果を踏まえ、 を正しく選び出すシミュレーションを武みた楛果、aldolase、TIM、 Taka-amylase、xylose isomeraseたついては、正しいシートを 第一侯烳の $\beta$ シートとして選び出すことに成功し、tryptophan synthase、Rubiscoた関しては、正しいシートが 2 番目の候補とし て選ばれましたが、flavocytochrome b2やglycolate oxidase では、選び出した侯㭪の中でい正しいシートはそれぞれ 4 番目、5 番 目となりました。また、逆平行 $\beta$ シートを持つenolaseについては正

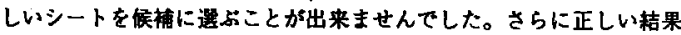
が得られるようなシミュレーションを行うべく現在検封中です。

$N$.Nagano, K.Nagano : Packing simulation of $\beta$ sheets in the TIM barrel.

\section{$1 \mathrm{~J} 1145$}

断片ベフォトトを用いたフォールデンケ消程の研究

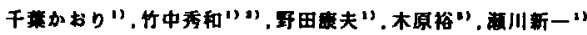
1) 时西学院、理 2) 现 ニコン（株）3）阅西医大、教

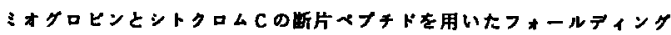
の研究は、これまて、我んを含めたいくつかのクルーブに上り集められて

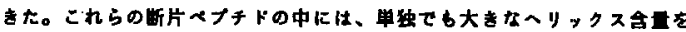

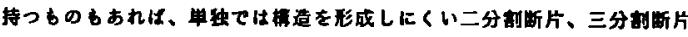

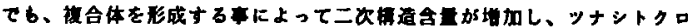

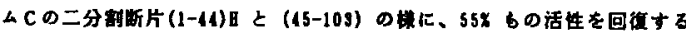
6のも轱されている。またミ才グロビン成して、モルテングロヒュー ル状慗でばけているといわれるEFへリっクスの部分の断片が、ムを

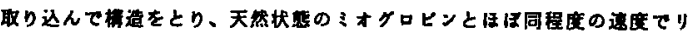

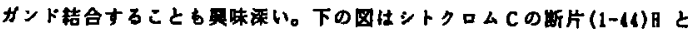

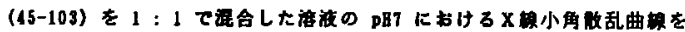

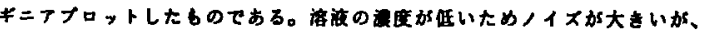

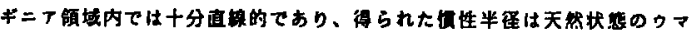

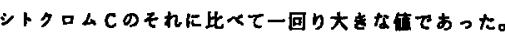

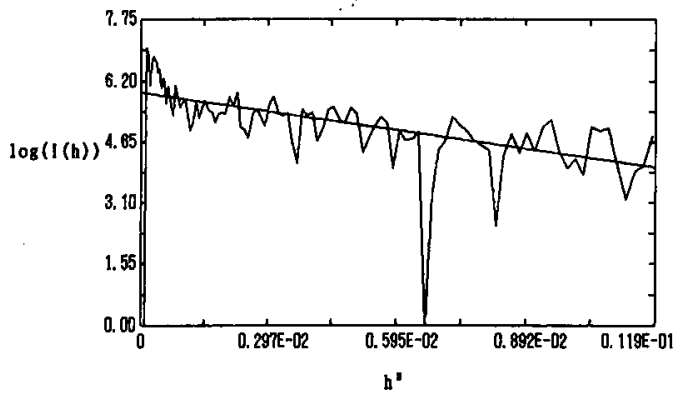

I. Chiba, H. Takenaka, Y. Noda, H. Kihara, S. Segava: A study on folding pathways using peptide fragments.
$1 \mathrm{~J} 1130$

$$
\begin{aligned}
& \text { クエンチ状熊にあるたん白䆝の自己集合理詥 } \\
& \text { O宝玉 充 永山国昭 } \\
& \text { （新技術事羓団永山たん白集种プロシェクト） }
\end{aligned}
$$

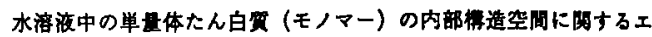
ネルキー麦面に㤌多数の梗小点があり、それらはときに高いエネルキー 障壁で腰てられていることが知られている。同椂に自己集合体中のたん 白分分子の内部粠造空間に関するエネルギー表面も被雑であろう。一股 に自己集合体中のたん白算分子は周りの分子から受ける相互作用により モノマー単独とは異なった内部棌造分布を持つであろう。ここで取り上

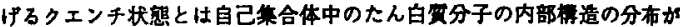
モノマーのそれに固定された状热でる。この固定化が自己集合体に乱

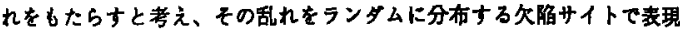
ちる。

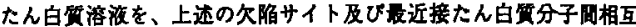
作用を持つ格子気体模型て考える。大分配閔数忙次のようになる。

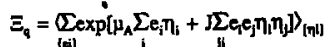

$$
\begin{aligned}
& \mu_{A} \text { : たん白贫分子の化学ポテンシャル/KT } \\
& \mathrm{J} \text { ：最近接分子間相互作用 } / \mathrm{KT} \\
& \text { 欠樎サイト： } \eta_{1}=0 \text {. 非久陥サイト： } \eta_{\mathrm{l}}=1 \\
& \text { 占有サイト： } \mathrm{e}_{1}=1 \text { - 非占有サイト }: \mathrm{e}_{1}=0
\end{aligned}
$$

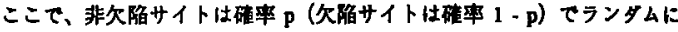

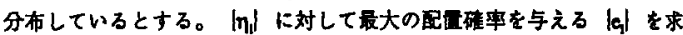

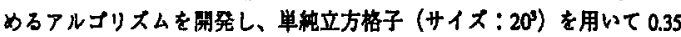
$\leq \mathrm{p} \leq 0.45$ の範围で盿算を行った。るの結果を柽告する。

M.Hogyoku and K.Nagayama : Theory of self-assembly for proteins in a quenched state

$1 \mathrm{~J} 1200$

$$
\begin{gathered}
\text { 部分配列を分子内的に入れ换えた蛋白得の特徽づけ } \\
\text { O吉田咠二*，梛川弘志 } \\
\text { (*北大·莱, 三菱化成生命研 })
\end{gathered}
$$

蛋白㑭のフォールティング中間体に閉する研究が最近注目さ

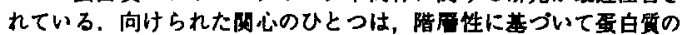
立体傋造を理解しようという立场に立つものである．㫘白質の天然 楼造は互いに依存しているたくさんの相互作用（あるものは一次西 列上近接した残基間のもの，別のものは一次配列上嘌れた残基間の もの）功っている，中間状熊の特徽は，高次椎造を通じた特異

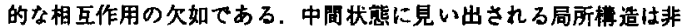
特異的大㻋水性极互作用により安定化されていることが示晙されて いる.これは本当に非特異的なるのなのだろうか？むし一次配列上 離れだ残基間の相互作用を選扷的に除いて行けば野生型蛋白颀の中 間状態に見い出される構造が同粎に観察されるのだろうか？

我々は，こ机まてに，蛋白兵の部分配列（蛋白翼のモシュー ルに相当する）を入れ掼えててきる変異㔻白领の特徽づを行って きた．对象は立体粠造の既知であるバクテリア由来のバルナーゼ(リ

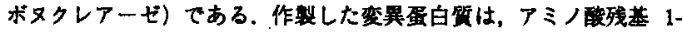
24 と25-52を入れ換えたナパルーセと 25-52 と53-73を入れ换えたバ ルセーナてある.この二つの变異蛋白質の物理化学的性所を，举光・ CD・ゲルろ過を用いて悯へた。

遠紫外のCDスペクトルから二つの変翼体は二次粠造を保持し ていることがわかった，バルセーナは近萦外の領域に強いCDスベク トルを示した．またトリフトファンの巣光を指栖とした尿素变性実 釾においてハルルーナは協同的な变性曲線を示した、後者二つの䃌

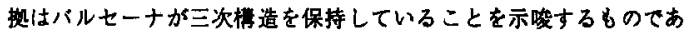
る.ナバルーセにはこれらの特徽は見い出されなかった。

野生型バルナーゼの中間状態の迲紫外CDスベクトルは変翼蛋 白啠のものと類似していた，得られた結果を三次掼造形成と二次棈

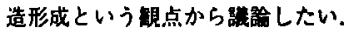

Yoshida. $K$, and Yanagawa, $H$. :

Characleri/ation of the permuted protein. 
I J 1215

パルナーゼのそジーール遗結体の梅造と機能

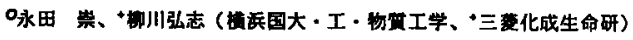

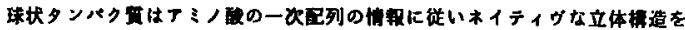
形成するが、モのフォールディンクの棈楮はまだ明かでない。我々はタンハク

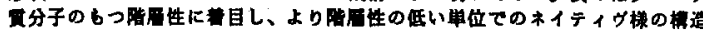

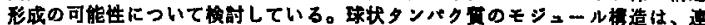

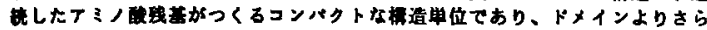
に小さ部品といえる。これまて、我々はりボヌクレナーゼの一租のハルナー

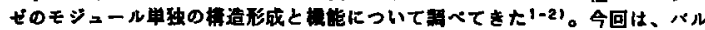

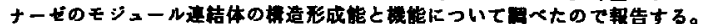

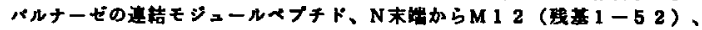
$M 13(1-73) 、 M 14(1-88) 、 M 15(1-98)$ \& 末竧加 9M56 (89-1 10)、M46(74-110)、M26(25-110)

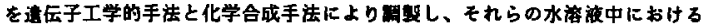

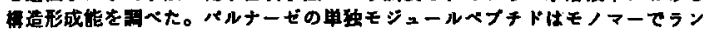

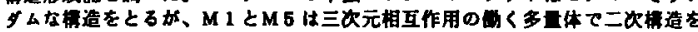

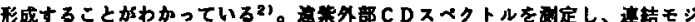

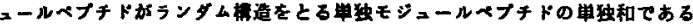

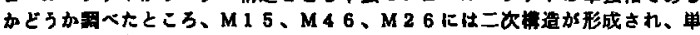
和でないことがわかった。また、M12、M13、M14は水溶液中で二

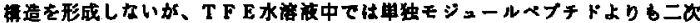
棓透を形成しやすいことがわかった。近柴外部CDと虽光スベクトルにより、

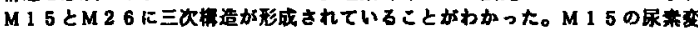

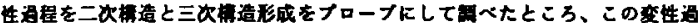

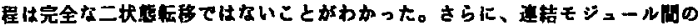
相互作用についてCDスべクトルとリボヌクレナーゼ活性を指洒にして同へた。 M15はM 6 と相互作用しなかったか、M56およひM46 とは相豆作用する ことがCDスヘクトルの结果からわかった。M 15 はM 56 と相互作用して、

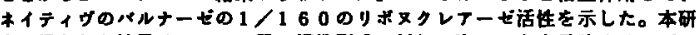

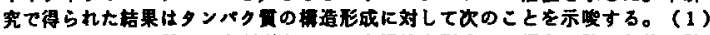

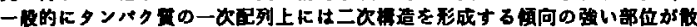

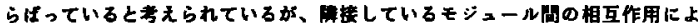

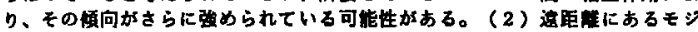

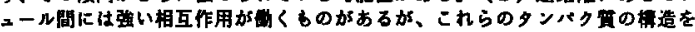

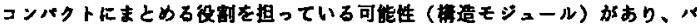
ヘナーゼにおいてはM1とM5の間にものような相互作用が影く。

1)B. Yanagava et al. . J. Biol. Chen. . 268:5861(1993). 2)K. Yoshida et al. Biochenistry, $32: 2162$ (1993).

T. Magata, H. Yanagara: Structure and function of connected nodules of barnase

\section{J 1400}

FOLDING KINETICS OF STAPHYLOCOCCAL NUCLEASE KALNIN,N. and KUWAJMA, K

Department of Physics, School of Science, University of Tokyo 7-3-1 Hongo, Bunkyo-ku, Tokyo 113

\footnotetext{
The effect of amino acid substitutions on the urea-induced kinetics of unfolding and refolding of staphylococcal nuclease $A$ (SNase) was studied by stopped-flow circular dichroism (CD) technique. The Escherichia coli strains AR120 carrying genes of SNase mutants, kindly provided by Dr. D.Shortle, were used to express and purify mutant proteins. Considering the protein stability determined by urea denaturation, the destabilizing amino acid substitutions (A69T, A90S and A69T+A90S) as well as stabilizing (V66L, G88V and V66L+G88V) were chosen for kinetic measurements.

The kinetics of unfolding accounts for two phases with the rate constants of $0.3 \mathrm{~s}^{-1}$ and $0.01 \mathrm{~s}^{-1}$ (for the wild-type), the first of which has only $7 \%$ of the total amplitude and is not affected by the mutations. The dominant slow kinetic phase of unfolding of A69T, A90S, A69T+A90S and V66L is also tolerant to the amino acid substitution, but accelerates with an increase in urea concentration. Since about $90 \%$ of the protein molecules in the absence of $\mathrm{Ca}^{2+}$ and ligands adopt $c$ is conformation of the peptide group 117 which is more stable than trans one, this pool of molecules appears to be responsible for the slow kinetic phase of unfolding.

The refolding of wild-type SNase and the mutants showed three wellpopulated kinetic phases, two of which having time constants of $10 \mathrm{~s}^{-1}$ and $2 \mathrm{~s}^{-1}$ (for the wild-type) were affected by the mutation.

The slowest refolding kinetic phase with a time constant of $0.02 \mathrm{~s}^{-1}$, which is thought to result from cis-trans isomerization of the peptide group preceding Pro1 17 neither depends on mutation, nor on urea concentration.

The fastest refolding kinetic phase corresponds to the refolding reaction going through the most favorable kinetic pathway which is not complicated by cis-trans isomerization. The three destabilizing mutations result in deceleration of the refolding, so that the corresponding increase in the transition state energetic barrier, $\Delta \Delta G^{\text {retold }}$, coincides with the difference in stability obtained at equilibrium, $\Delta \Delta \mathrm{G}^{\text {equilibr }}$. The stabilizing mutations accelerate refolding, but the correspondence to the equilibrium data for the $G 88 \mathrm{~V}$ and V66L+G88V mutants is not clear. Thus, with the exception for the residue G88 located within the extended loop, the intramolecular interactions in the transition state are very similar to the native ones.
}

柴外倾域们傮光二色性 (UVCD) スペクトルに对する

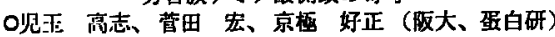

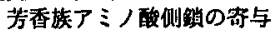

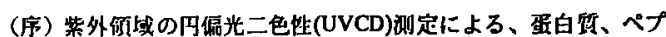

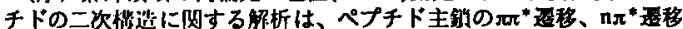
などに関速する 175nmから250nmまでの波長领域のCDスペクトルに 対して、各二次情慥に対応する参照スペクトルを最小二乘フィッティ ングさせることにより行われる。本研究ては、200nmから250nmまで の波長领域のCDスペクトルに対する芳香族了ミ/酸侧銷の泀与亡、 この二次槛遮解析に与えろ影暨についてに以下の方法で考察した。

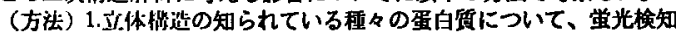

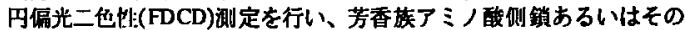
隣接アミド亚との相互作用に由来する光学的異方性因子 $\mathrm{g}_{\mathrm{p}}$ を求めた。

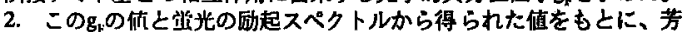
香族侧敍まわりに由来する異方性のCDスペクトルに対する菽与を求 めた。またこの異方性を生ずる原因について考察した。

3.上記の寄与と、最小二采フィッティングによる二次構造解析の阹に 用いられる参嬖スペクトルを比较し、その影郘に関して考察した。 参照スペクトルは、化学合成モテルペプチドのCDスペクトルから得 られるものや、程々の蛋白兵のCDスペクトルから胁出されたものな どを用いた。

(結果) 多くの蛋白啠において、芳香旗侧销まわりに由来する光学

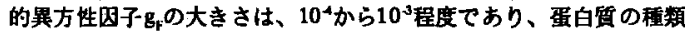
により異なっていた。また、異方性については、芳香蔟アミ/酸侧 鎖と㮦接了ミト基との相互作用のみに由来するとは考えにくいスペ

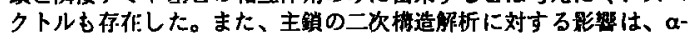
helix, $\beta$-shcet, $\beta$-turn含量の逢いにより異ることもおきらかとなった。

このように今回の䂗究では、ジスルフィド結合や金属蛋白質の金 属イオン四似部位のCDスペクトルへの寄与などとならひ、まだ不明 な点の多い桨不族発色団のCDスペクトル人の守与について朋かにし

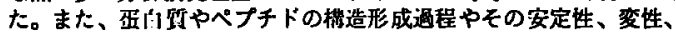
機能発現に阅わる橪造変化、他の分子との相互作刃の研究などの赎 には、200nmから250nmまでの波長領域のCDスペクトルが用いられ ろことが多いが、この际には、芳香矮侧销まわりに由来する異方性 のCDスペクトルに対する栔与を十分に考虑する必姴がおることが明 かとなった。

T.Kodama, H.Sugcta, Y.Kyougoku: Aromatic Side-Chain Contribuions to the Ultraviolet Circular Dichroism of Proteins

$1 \mathrm{~J} 1415$

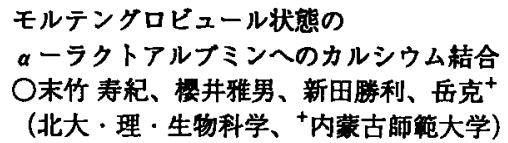

$\mathrm{Ca}^{2+}$ 秸合タンバク質であるa-ラクトアルブミン $(\alpha-\mathrm{LA})$ では、完全変性からの折りたたみ過程に、モルテングロビュ ール状態と呼ばれる安定な中間体が存在することが知られ ており、このモルテングロビュール状態には $\mathrm{Ca}^{2+}$ が桔合し ていることが報告されている。しかし、このことはウシ -LAについてのみ確かめられたにすきない。

本研究では、ヒト $\alpha$-LA のモルテングロビュール状態に おける $\mathrm{Ca}^{2+}$ の寄与について研究することを目的とした。そ の結果、ヒト $\alpha$-LAのモルテングロビュール状態には $\mathrm{Ca}^{2+}$ が結合していないことが確䜑された。

そこで、他種の $\alpha$-LA についても同様の測定を行なったと ころ、そのモルテングロヒュール状態にはウシ $\alpha \cdot$ LA と同 梯に $\mathrm{Ca}^{2+}$ か桔合しているものと、ヒト $\alpha \cdot \mathrm{LA}$ のようにCa ${ }^{2+}$ が結合しないものとがあることがわかった。このことはモ ルテングロビュール状態へのCa ${ }^{2+}$ の桔合は生理的に重要な 意味を持っていないということを示唆している。

更に、ヒト $a \cdot \mathrm{LA}$ の粗造転移では、卷き戻りの速度定数 のみが $\mathrm{Ca}^{2+}$ 湌度に依存しており、このことから、モルテン クロヒュール状態と天然状態の間の效力学的に高エネルギ

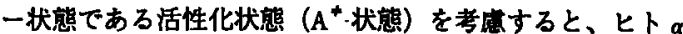
-LA ではモルテングロビュール状態からA+.状熊人と変化 する際にC ${ }^{2+}$ 結合部位が形成され、天然状驡に至るものと 思われる。

T. Suetake, M. Sakurai, K. Nitta, Yue $\mathrm{Ke}: \mathrm{Ca}^{2+}$ Binding on the Molten Globule State of $\alpha$-Lactalbumin 
$1 \mathrm{~J} 1430$

トリフルオロエタノールによるア-ラクトグロブリン の楼造哣移

○後藤倹児、白木足太郎、十西川建

（阪大·理·生物、十蛋工研）

トリフルオロエタノール（trifluoroethanol；ＴＦＥ）が存在する

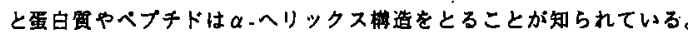

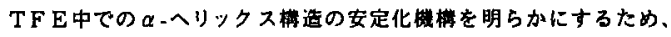
タ-ラクトグロブリンをはじめとする程々の蛋白算に対するTFEの 効果を円二色性（CD）スベクトルを用いて調べた。

剆定を行なった全ての蛋白每は、T F Eを添加すると $\alpha$-ヘリック 又含量が增した。ところが、TFEの好果は蛋白異によって大きく

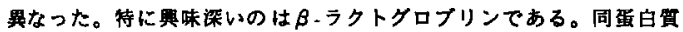

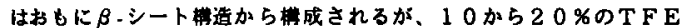
泿度の間で坫同的にヘリックス媾造へ忶移した。これとは対照的に、 同じく $\boldsymbol{\beta}$-シートからなる免度グロブリンのC、フラダメントでは、へ リックスへの忶移は馀々におこり最转のヘリックス含量も低かった。 一方、ネイティプでヘリック ス含吾の离い蛋白冥はT F E 存在下でもへリックス含至は 高い傾向にあった。

TFE中でのへリックスの 安定性は近垔椎相互作用によ て决まると推定される。二次 棈造予湖によると $\beta$ ーラクト グロプリンは $\beta$ 蛋自異である にもかかからず、 $\alpha$ 蛋白賁と 予想されている。同蛋白買の $\beta$-梅造の形成の途中に $\alpha$-ヘ リックスが形成されることも 起こり得ると考えられる。

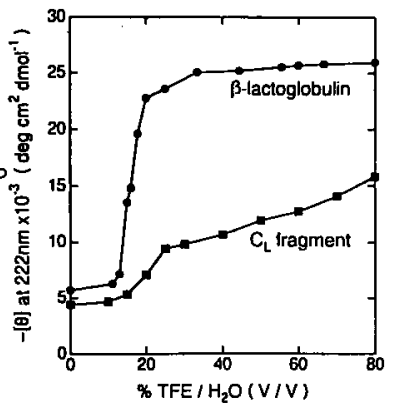

图：TFEによる
Y. Goto, K. Shiraki, K. Nis hikawa: Trifluoroethanol-induced confomational transition of $\beta$-lactoglobulin.

1 J 1500

人工蛋白筫の熱力学とそのの構造的 な解 积

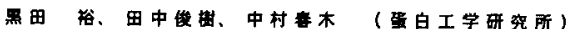

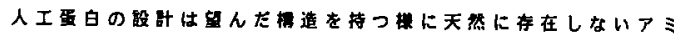
八酸列を決める作萧のことである。ここ数年、多くの研究グル

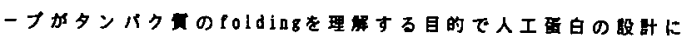

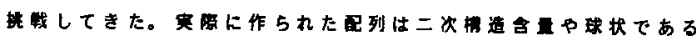
ことからー見成功したかの楞われた。しかし、こくわすかな

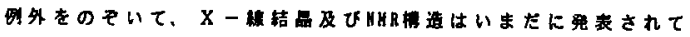

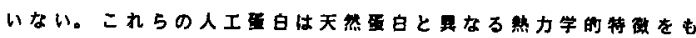

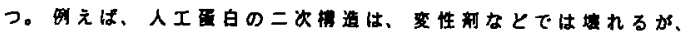
温度を上げても变性しない。さらに、天然正白ではとととと测 されない低温帘性がよく見られる。

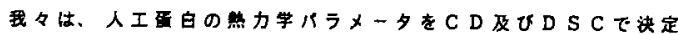

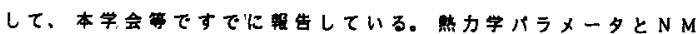

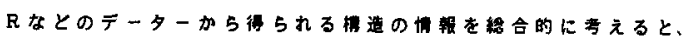

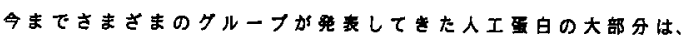

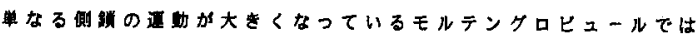

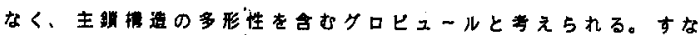

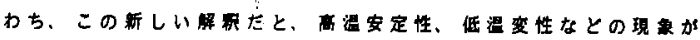

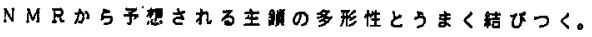

Y. Kuroda, T. Taaka, B.llakaura: Structural interpretation of the thermodynales of de novo designed proteins.
$1 \mathrm{~J} 1445$

$\beta$ •ラクトグロブリンのフラグメントの立体椎造

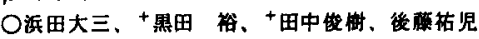
（阪大·理·生物、十蚠白工学研）

蛋白筫から単唯したベブチドフラグメントのトリフルオロエタノー ル (Irifluoroe thanol：T F E) 中での二次榑造は、ネイティブ槽道 における二炊㭗造と相関が高いと考えられてきた。

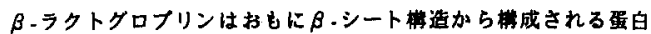
筫であるが、T F Eを添加すると $\alpha$ 、ヘリックス槽造が普しく安定化 されることが明らかとなった。そこで、 するいくつかのベプチドを合成して、それらの立体满造を開べた。

ネイティプ棈造では $\beta$-シートであるが、西川と野口（1）により

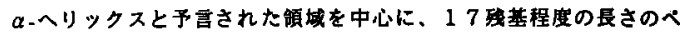
ブチド、数種㓋を合成した。それらの二次粗造を円二色性スべクト ルを用いて影べたところ、すべてのベブチドはT F Eが存在しない と高度に变性していた。しかし、TF E を添加すると $\alpha$ オリックス 含量は著しく增加した（图）。

これらの轺果から、 $\beta$-ラ クトグロブリンで見いださ れた $\alpha$ ヘリックスを形成し やすい傾向は、同蛋白買由 来のベプチドにおいても既 淜されることが明かとなっ た、TFE存下でのベフ チドの二次梅造とネイティ ブ遀とは、かならずしも 相閲しないことを示す。 (1) Nishikawa, K, \& Noguchi, T. (1991) Methods Enzymol. 202, 31-44.

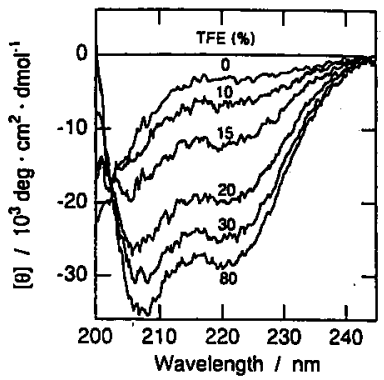

图：日・ラクトグロフリンのフラグメント： W(61)ENGEC AQK KIIAEKTK(77)のCD スベクトル. pH 2, $20 \mathrm{C}$.

D. Hamada, Y. Kuroda, T. Tanaka, Y. Goto: Conformation of the peptide fragments of $\beta$-lactoglobulin.

$1 \mathrm{~J} 1515$

'H-NIR による卵白アルプミン(OVA)の mol ten-globule 状態 の研究

○曾我美 勝，恵良聖一

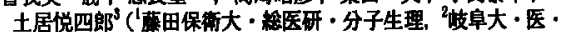
2生理, “京大·食餅)

Xosekiら (1988)は 0VA分子は pH 7.0(N型)から, pH 2.0(E型)にすると, E型の

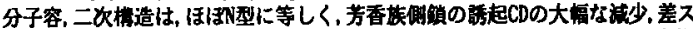

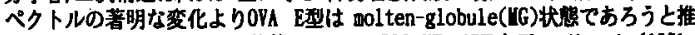

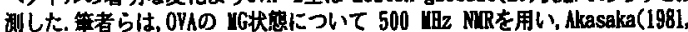

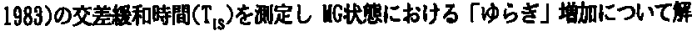
析した.

OVAのpD 7. 29(N型)，3.08(E型)，0.10 « Clの D,0 海について, Akasakaの inversion recovery法を用い, $-2.45\left(r \mathrm{H}_{2} / 2 \pi \sim 107 \mathrm{Bz}\right), 0.40(39 \mathrm{~Hz})$, $7.13(69 \mathrm{HZ}), 8.65 \mathrm{ppm}(107 \mathrm{~Hz})$ を $\mathrm{f}_{2}$ 照射し. $\mathrm{T}_{15}$ 值を刺定した.04のの各ビーク

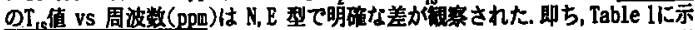

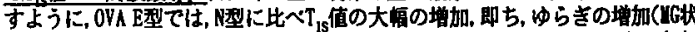

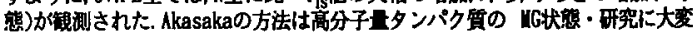
有用な方法であろう.

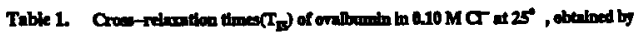
the thersiou recorrey necthod

\begin{tabular}{|c|c|c|c|c|c|c|c|}
\hline \multirow[b]{2}{*}{ pD } & \multirow[b]{2}{*}{$t_{2}(\mathrm{ppm})$} & \multirow[b]{2}{*}{$\gamma \mathbf{E}, 2 x(\mathrm{Al})$} & \multicolumn{5}{|c|}{$\mathbf{T}_{\mathbf{B}}(\mathbf{x \in c})$} \\
\hline & & & $-\mathrm{CH}_{3}$ & $8-\mathrm{CH}_{2}$ & $C_{n} \mathrm{H}$ & AROM & EIS(CAB) \\
\hline $\begin{array}{l}729 \\
3.08\end{array}$ & -2.45 & 107 & $\begin{array}{l}230 \\
234\end{array}$ & $\begin{array}{l}127 \\
320\end{array}$ & $\frac{200}{420}$ & $\begin{array}{l}2.25 \\
3.43\end{array}$ & $\frac{197}{414}$ \\
\hline $\begin{array}{l}7.29 \\
3.08\end{array}$ & 0.40 & 39 & $\begin{array}{l}0.60 \\
0.58\end{array}$ & $\begin{array}{l}0.98 \\
180\end{array}$ & $\begin{array}{l}1,59 \\
276\end{array}$ & $\begin{array}{l}0.74 \\
1.35\end{array}$ & $\begin{array}{l}28 \\
206\end{array}$ \\
\hline $\begin{array}{l}7.29 \\
3.00\end{array}$ & 7.13 & 69 & $\begin{array}{l}0.76 \\
1.09\end{array}$ & $\begin{array}{l}1.12 \\
1.66\end{array}$ & $\begin{array}{l}1.72 \\
235\end{array}$ & $=$ & $\underset{15}{01}$ \\
\hline $\begin{array}{l}7.29 \\
3.06\end{array}$ & 805 & 107 & $\begin{array}{l}0.75 \\
1012\end{array}$ & $\begin{array}{l}2.15 \\
1.69\end{array}$ & $\begin{array}{l}173 \\
2.44\end{array}$ & $\frac{121}{140}$ & 二 \\
\hline
\end{tabular}

U. Sogani, S. Era, A. Takasaki, K. Kuwata, T. Koseki, E. Doi: 'H-NIR studies on the molten-globule state of ovalbumin 


\section{$1 \mathrm{~J} 1530$}

a-ラクトアルフミンのC-ヘリックスの安定性

○清水昭夫、池口雅道、須貝新太郎（剆価大·工）

a-ラクトアルフミンにおいて天然状態で形成されてい るのと同様のC-ヘリックスがモルテン・ダロビュール（ MG）状態ても形成されいる[1]こと、C-ヘリックス領 域のペプチドは水溶液中ではヘリックスを形成しないこ とからヘリックス形成には此较的迋距蜼のアミノ酸残基 間相互作用が重要である [2] ことがすでに報告されてい 万。

本研究では牛とモルモット $a$-ラクトアルフミンのC-へ リックス（D84〜G100）および牛a-ラクトアルプミンの C-ヘリックスとMG状態においてY 103、W104、H 107 よ り形成されている㻋水性クラスタ一領域（D84〜H107） を含む2種類のペブチドを合成し、CD（222nm）を用い たトリフルオロエタノール滴定実験からこれらのベプチ ドの安定性を雨へた。その結果、1）N末端をアセチル化 してもヘリックスの安定性は変わらない。2）牛とモル モットのC-ヘリックスの安定性はほとんど同じでるこ とが明かとなった。これらの結果をさらに解析し トアルフミンのC-ヘリックスの安定性を識諭する。

\section{【参考文献]}

[1] Alexandrescu et al. (1993) Biochemistry 32, 1707-1718

[2] 清水、池口、須貝（1994）第67回日本生化学大会

I J 1600

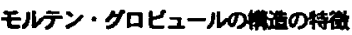

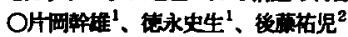
大服大学・理学部·宇宙地球、生物 ${ }^{2}$

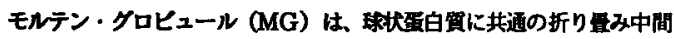

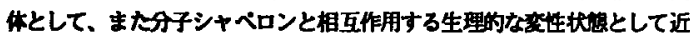

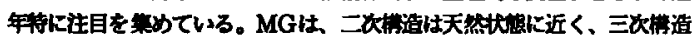

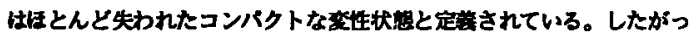

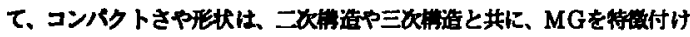

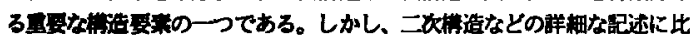

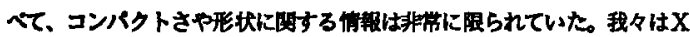

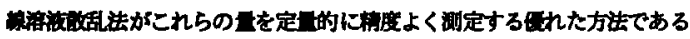

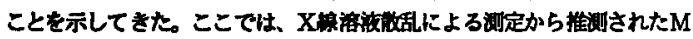

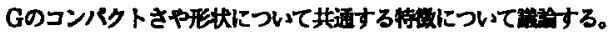

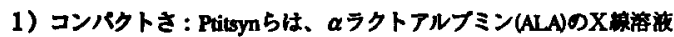

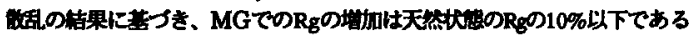

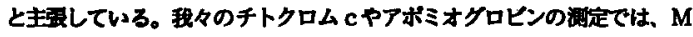

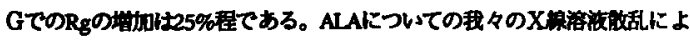

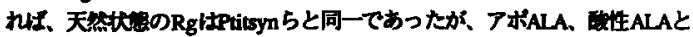

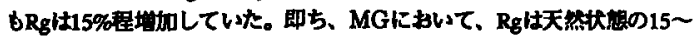

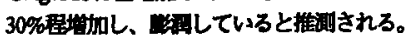

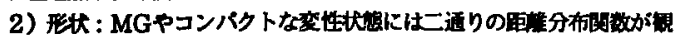
列される。チトクロムc PALAのMGの示す単ーピークのP(r)とアボミオ グロピンのMGPSNase フラグメントの示す二相性のP(r)である。前者は球

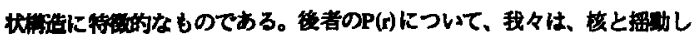

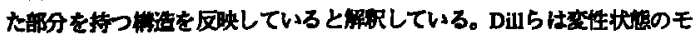

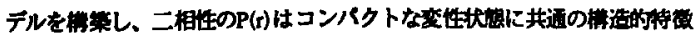
であると主㜊している。二相性のP(r)は必ずしもMGに共通するものでは

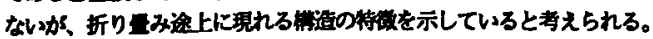

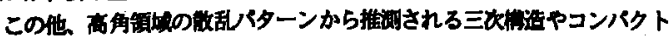

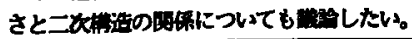

M. Kataoka, F. Tokunaga, Y. Goto: Structural Characterization of Molten Globule.
$1 \mathrm{~J} 1545$

モルテン・グロビュールにおけるヘリックス安定化

○池口雅道、清水昭夫、須貝新太郎（創価大・工）

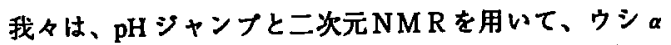
ーラクトアルブミンのモルテン・グロビュール (MG) 状 態に拐ける主鎖アミドブロトンの水素交換反応を追跡し、 その保護度からMG状㲘におけるCヘリックスの安定性を 見皘った [1]。Cヘリックスに相当するペブチドは水溶 液中でヘリックスを形成せず、MG状龍におけるへリック ス形成には遠隔残基間相互作用が重要でることが示唆さ れた[2]。ここては、モルモットaーラクトアルプミン $[3,4]$ 、ミオタロロビ $[5,6] 、$ 、トクロームc $[7,8]$ 等 のMG状態について得られた類似の耛果とあわせて、M G 状態てのヘリックスの安定性と相当するペブチドでのリッ クス安定性を比較し、MG状態てのヘリックス安定化の程 度とタンバク質全体の、あるいはヘリックス部分の疎水性 度等との相関を調べた耛果を報告し、MG状態でのヘリッ クス安定化の機棈を議論する。

【参考文献】

[1] 池口、清水、須貝 (1994) 第67回日本生化学大会

[2] 清水、池口、須貝 (1994) 第67回日本生化学大会

[3] Buck et al. (1994) J. Mol. Biol. 237, 247-254

[4] 清水、池口、須貝 (1994) 生物物理学会第32回年会

[5] Hughson et al. (1990) Sience 249, 1544-1548

[6] Waltho et al. (1993) Biochemistry 32, 6337-6347

[7] Jeng et al. (1990) Biochemistry 29, 10433-10437

[8] Kuroda (1993) Biochemistry 32, 1219-1224

$1 \mathrm{~J} 1615$

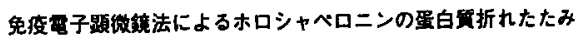
中間体結合部位の钼察

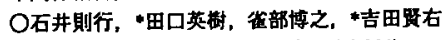
(理研・フロンティア、*束工大・皆源研)

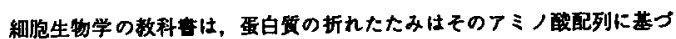

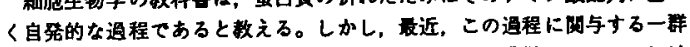
の蛋白夏，分子シャベロンの存在加明らかとなった。分子シャベロンには いくつかのフォミリーがあるが，最も主く知られているのはシャベロニン

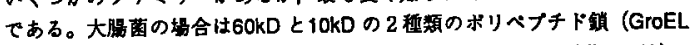
とGroES) は別々に精整されろが，好热菌Thermus thermophilus では，

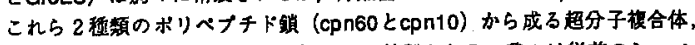
ホロシャベロニン (T. holo-cpn) として精彆される。我々は従前のシャベ

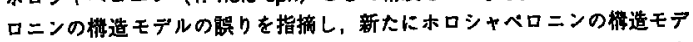
ルを提出したが，果たしてホロシャヘロニンがとこで基の折れたたみ中 間体を桔合するのか，免痤宙子期徽鏡法により実像として明らかとした。

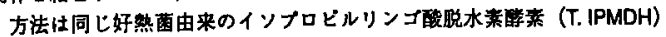

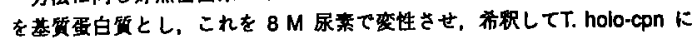

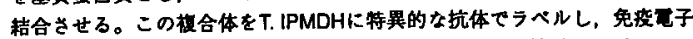
影微跣法に上り数察を行なった。更にこの抗体に対する抗体て 2 重にラベ ルし、桔果を確実なものとした。

その桔果，通常仕弾丸の上うな側面像を見せるT. holo-cpnに上述の处理 を行なうと弾丸の底の部分に而量の增加が祸められた。2 種類の抗体を用 いて2重にラヘルしたものでは質量の增加加更に影著となった。

ホロシャベロニンは中心妕方向に空洞のある弾丸のような格好をしてお ク、折れたたみ中間体はこの弾丸の底の中心部分に䠜合することがわかっ

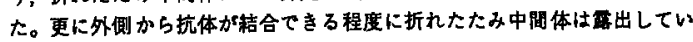
ると思われる。

N. Ishii, H. Taguchi, H. Sasabe, M. Yoshida : Observation by immuno-electron microscopy of binding site to folding intermediates on hölo-chaperonin. 


\section{$1 \mathrm{~J} 1630$}

シャペロニンGｒｏＥLと通元-a-ラクトアルブミンとの 相互作用

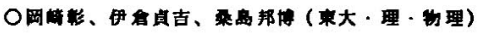

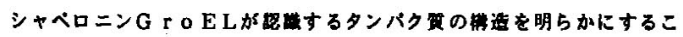

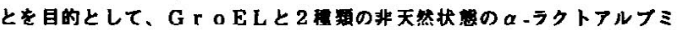
ンとの相互作用を政ヘた。 $\alpha$-ラクトアルフミンはカルシウム蛣合タンバ

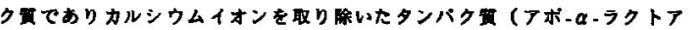

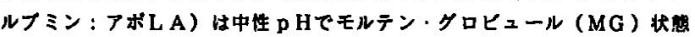
をとる。G r ○ E LとMG状触にあるアボLAとは相互作用しないことを

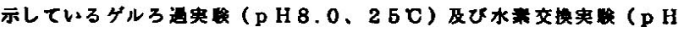
$6.0 、 20 \mathrm{C})$ の苚果は、非年の本学会で脕表した。(Okazaki et al. (1994): Nature S tructural Biology, in press) 珑べるうに K C I

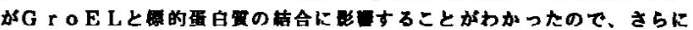

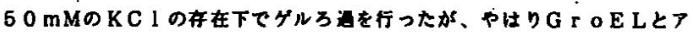

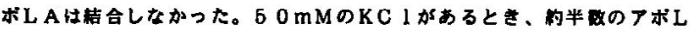

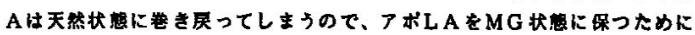
この実帏は 37 Cで行った。

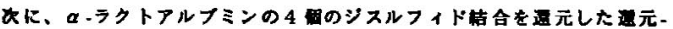

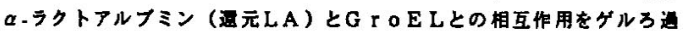

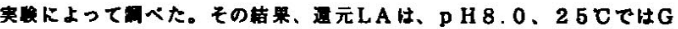
roELに船合しないが、50

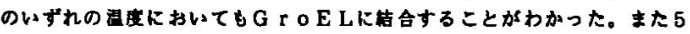

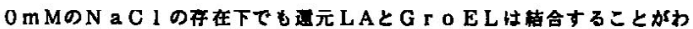

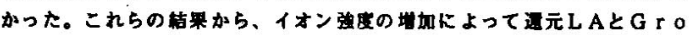

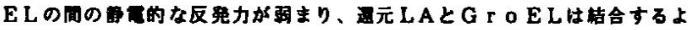
アになるのではないかと思われる。

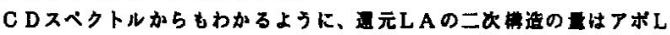

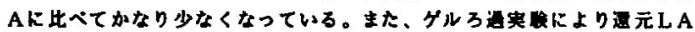
はアボレAに比へて分子サイスが大きいと思われる。このように、G r 。

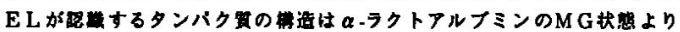
より解れた相造であるといえる。

A.Okazaki, T.Ikura, K.Kuwajima

Interaction bet ween the chaperon in GroEL and reduced- $\alpha-1$ act album in

1 J 1700

NMRによろCINC/g r ○の 1 量体- 2 量体平得の解

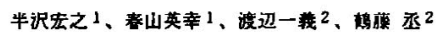

（1三共分析代时研、2サイトシダル研)

C I N C / g r o (Cytokine Induced Neutrophil Chenoattractant) は ラットにおいて好中球の茛走活性を有し、炎症の初期迥程において重要な湖 きを担う 72 残基からなるサイトカインである。I L -8 family と呼ばれ

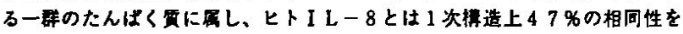
有する。

C I N C /g r oは生理的条件下においては、ゲルろ通の実㧎より、2 量 体で存在していることが明らかになっており、既に、200 0 m a C I

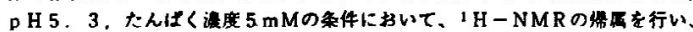
2 量体での3次元得造を決定した。

一方、N a C I 非存在下に扔て、畦 水中のHOHAHAスペクトルに、1次 樓造から予想される以上のNMRシクナ ルが䤄测され、それらは图、に示す上う に、 $\alpha H ， \beta H の$ 化学シフトが同じで、N Hの化学シフトのみ異なるペアとして煋 洞された。こんら Hの网に交換のシダ ナルか観测される亭から (图b)、何ら かの 2 状態が平街にあることが分かった。 超透心分析により、N a C 1が存在しな 以呀合、みか梳の分子量が 2 量体の示才 べき优より、小さくなっていることから、

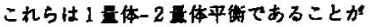
明らかになった。

そこて $200 \mathrm{mMNaClpH} 5.3$ に おける带属をもとにN a C I 非存在下で のN Hシダナルの偙保を行い、1 1 体2 量体での化学シフトの差から 2 量体形 成による㭗造装化を解析した。

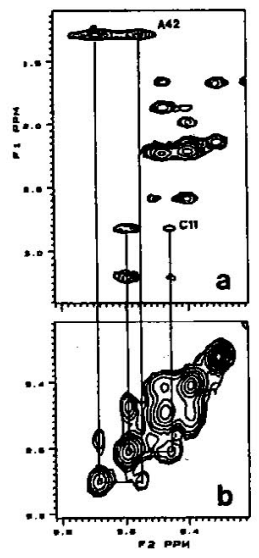

H. Hanzawa, H. Haruyama, K. Watanabe and S. Tusruhuj $i$;NMR analysis of monomer-dimer equilibrium of CINC/gro.
$1 \mathrm{~J} 1645$

牛IV型コラーゲンからのゲル状会合体の再構成と その構造

中里浩一,村岡正敏,安達栄治郎・,武田康,林利彦

（東京大学・教養, 大腵大学・医”）

基底膜棬成成分と基底膜超分子構造の関係については $\mathrm{H}$ S腫㾝組織から抽出されたIV型コラーゲン、ラミニンなど を用いた研究がなされている。E H S 腫窝組織から抽出し たIV型コラーゲンは他の基底膜構成成分ラミニン、ヘパラ ン硫酸プロテオグリカンと共存するとゲルを構成する。こ れはマトリゲルとして細胞培羔の基質として用いられてい る。E H S 腫瘍由来IV型コラーゲンのみからの in vitroの

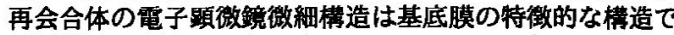
ある網目構造と似ているが、絧の目の大きさが一致しない。 他の基底膜構成成分との混合により、基底膜微細構造が構 成されると考えられてきた。

今回、IV型コラーゲンを主成分とする牛レンズカプセル 酢酸抽出物を $4{ }^{\circ} \mathrm{C} に て 20 \mathrm{mM}$ リン酸緩街液 (pH 7.3) $150 \mathrm{mM} \mathrm{NaCl}$ に24時間透析するとゲル状の会合体が誢察さ れた。ゲル会合体の力学的強度の差異を検討するために酢 酸抽出物を再会合させた後、遠心により変形する割合を湘 定し、ゲルの物理的性質を検討した。レンズカプセル酥醇 抽出物からなるゲルは、1) 低温 $\left(4^{\circ} \mathrm{C}\right)$ のほうが強固で、 高温 $\left(28^{\circ} \mathrm{C}\right)$ では脆弱である。2）力学的強度の獾得には 16時間以上を要する。3) 力学的強度は $4{ }^{\circ} \mathrm{C}$ 処理後、 $28^{\circ} \mathrm{C}$ にするなど温度を摇り戻すことによって半可逆的に変化す る。強固なゲル状を呈した再構成構造体について急逨凍結 後Pt-Cレブリカを作製し、電子影微鏡で観察した。その 結果：1）基底膜構造類似のネットワーク構造が多数の視 野において観察され、2）その網の目の枝分かれ点間の距 離が平均 $19.6 \mathrm{~nm}$ と基底膜構造とほほ同一であった。以上 の結果は、これまでの通説と異なり、基底膜構造の物理的 強度およびその微細骨格構造はIV型コラーゲンのみによっ て規定されることを示唆している。

\section{$1 \mathrm{~J} 1715$}

$\mathrm{F}$ ーアクチンによる二次元縞模様の形成

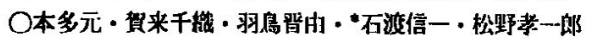
(長同技街科学大学・生物系、早船田大学・理工学部)

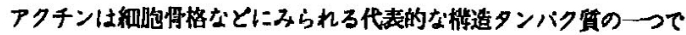

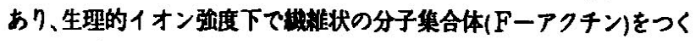
ろことが知られている，我いはこのFーアクチンの溶液が、ガラス扳上

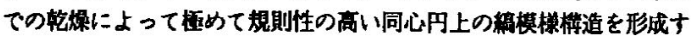
ろことを見いだした。この縝模様は3〜4 $\mu \mathrm{m}$ の間隔て周期的に並んでお ク、武料を竞煤させる際の温度を下げるにしたがって間隔は広くなク、

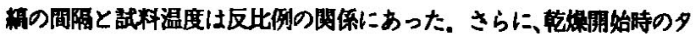

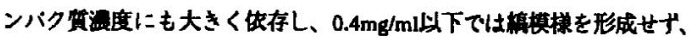

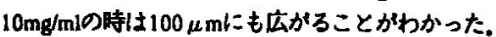

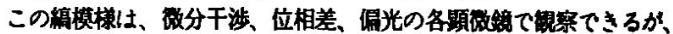

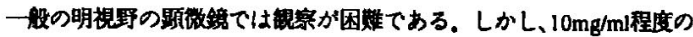

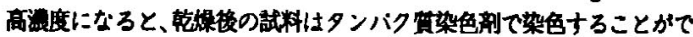

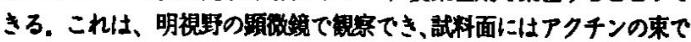

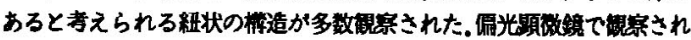

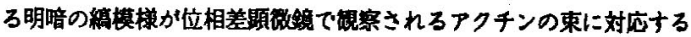

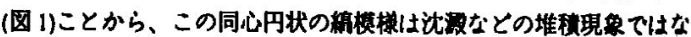
く、放射状に並んだ波状のアクチンの束によって形成きれていると考え られる.

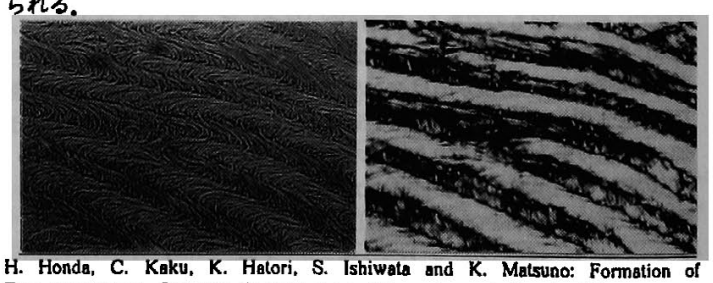
Two-dimensional Periodic Texture from Filamentous Actins in Vitro. 